\title{
Using Radiocarbon Dates and Tool Design Principles to Assess the Role of Composite Slotted Bone Tool Technology at the Intersection of Adaptation and Culture-History
}

\author{
Mikael A. Manninen ${ }^{1}$ (D) Vitali Asheichyk ${ }^{2}$ (D) Tõnno Jonuks $^{3}$ (D) \\ Aivar Kriiska $^{4}$ (D) Grzegorz Osipowicz $^{5}$ (D) Aleksei Nikolaevich Sorokin ${ }^{6}$. \\ Aliaksandr Vashanau $^{7} \cdot$ Felix Riede $^{8}$ (D) Per Persson $^{9}$
}

Accepted: 28 February 2021/ Published online: 17 March 2021

(C) The Author(s) 2021

\begin{abstract}
Slotted bone tools are an iconic example of composite tool technology in which change in one of the components does not require changing the design of the other parts. Commonly, slotted bone tools are seen through the lens of lithic technology, highlighting organizational aspects related to serial production of insets, reliability and maintainability. In this framework, slotted bone tool technology is associated with risk aversion in demanding environmental settings. Here, we provide the first overview of radiocarbon-dated slotted bone tools in northernmost Europe and the East European Plain, including 17 new direct dates on pitch glue, and show that the Late Pleistocene to Middle Holocene period of inset slotted bone tool use in this area shows marked variation and idiosyncrasy in associated lithic technology against a trend of continuously warming climate. We suggest that historical specificity and pathdependence, rather than convergent evolution, best explain the variability seen in slotted bone tool technology in the studied case, and that slotted bone tools in general formed an organizationally flexible, adaptable and hence likely adaptive technological solution that met a wide variety of cultural and technological demands.
\end{abstract}

Keywords Slotted bone tools · Europe East European Plain · Mesolithic $\cdot$ Composite tools . Organization of technology

Mikael A. Manninen

mikael.manninen@helsinki.fi

Extended author information available on the last page of the article 


\section{Introduction}

Technologies that combine small replaceable lithic insets, slotted bone shafts and wooden hafts into composite tools and weapons were produced in many parts of the world up until the Late Holocene. Microliths appear fairly early in prehistory (cf. Burdukiewicz, 2005; Elston \& Kuhn, 2002; Lewis et al., 2014) are strongly associated, for instance, with early modern humans in the African Middle Stone Age (e.g. Wadley, 2015), but evolve repeatedly in different parts of the globe in a process that converges on similar design principles (Clarkson et al., 2018). The patchy geography, repeated appearance and episodic disappearance of microlithic technology and the complex composite tools it implies suggest that this technology cannot be seen as the endpoint of a preordained modal development, nor can it readily be seen as a global adaptive optimum.

In an influential paper on microblade and slotted bone point technology in Late Pleistocene northern Asia, Elston and Brantingham (2002) suggested a strong link between an efficient risk-minimizing microlithic technology and composite slotted bone tool technology. Although Elston and Brantigham noted that the use of bone tools with inset microblades in their area of study was contingent and situational, the occurrence of inset technology in the northern latitudes has since often been regarded as evidence of design choices rooted in risk-minimization in cold and harsh environmental conditions (e.g. Elston et al., 2011; Graf, 2010; Rabett \& Piper, 2011; Qu et al., 2012). Other researchers have suggested links between production of microblades, inset bone tools and high residential mobility, as raw material efficiency and serial production reduce tool-stone carrying costs and provide a means of reducing the risk of ending up with no suitable tool-stone when mobility is high and the foraging range large (e.g. Goebel et al., 2000; Hartz et al., 2010; Yi et al., 2013). Barton et al. (2007) also note that there is evidence suggesting a continuous use of composite tool technology over the Late Glacial Maximum (LGM) in northern China, and that the expansion of microblade technology after the LGM was based on a substrate of composite tool technology employing bipolar-on-anvil reduction on various materials in pebble form (see also Brantingham et al., 2004; Madsen et al., 2001).

In northern Europe and on the East European Plain (Fig. 1), slotted bone tools have a long history of research as parts of Mesolithic hunter-gatherer-fisher tool inventories (e.g. Clark, 1936; Gurina, 1956; Indreko, 1948; Lidén, 1942; Pälsi, 1920; Sarauw, 1904). The Early and Middle Holocene in this region was a time of rapid climatic warming interrupted only by short cooling events (e.g. Feurdean et al., 2014; Fleitmann et al., 2008; Seppä et al., 2002, 2009; Veski et al., 2015); the climatic and environmental settings thus differing considerably from the cold, dry and variable Late Pleistocene conditions of northern Asia.

A scenario purporting a connection between inset tool technology of the Mesolithic East European Plain and South Scandinavian Maglemose and Kongemose (ca. 11,8007400 BP) cultures has gained support in recent years from studies indicating Postglacial dispersal of bone tool and lithic pressure blade production technologies - probably alongside an influx of people - in the Scandinavian Peninsula from the east (Bergsvik \& David, 2015; Damlien, 2016; David, 2009; Sørensen et al., 2013). The same culturehistorical connection across the Baltic Sea, based on similarities in slotted bone tool technology and other typo-technological details, was suggested already by precocious synthesizers such as Clark (1936) and Lidén (1942). Fundamentally, however, research 


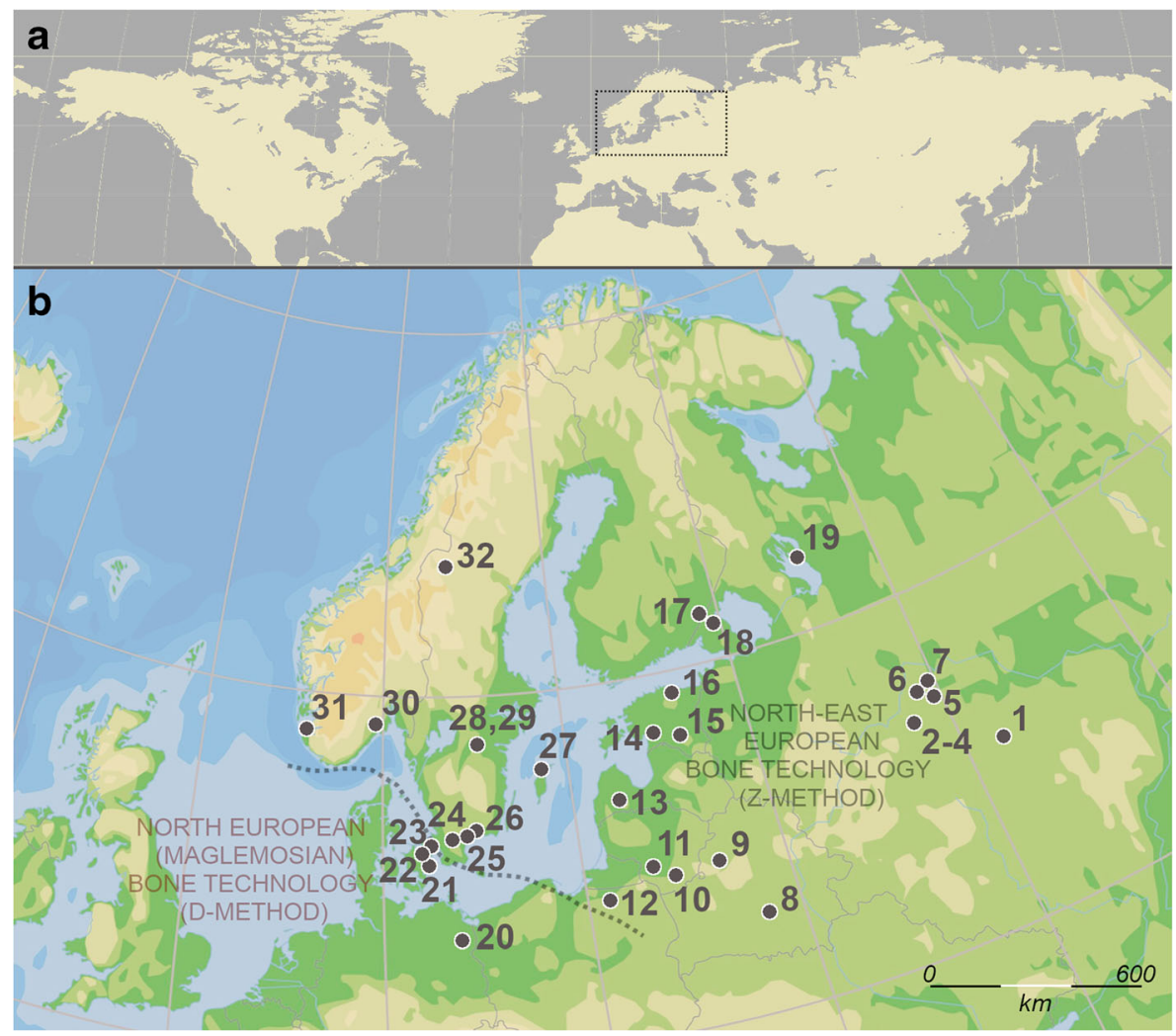

Fig. 1 a The Northern Hemisphere and the area discussed in the paper. b Sites and locations: 1. Karacharovo; 2. Minino 2; 3. Zamośtje 2; 4. Zamośtje 5; 5. Sakhtysh 14; 6. Ivanovskoje 7; 7. Stanovoje 4; 8. Aziarnoje 2B; 9. Michnievičy; 10. Vaikantonys; 11. Obšrūtai; 12. Tłokowo; 13. Zvejnieki II; 14. Pärnu River; 15. Ulbi; 16. Kunda Lammasmägi; 17. Muilamäki; 18. Antrea Korpilahti; 19. Yuzhniy Oleni Ostrov; 20. Groß Fredenwalde; 21. Tuse Hauge; 22. Vedbæk; 23. Tågerup; 24. Rönneholms Mosse; 25. Barum Grave; 26. Norje Sunnansund; 27. Stora Bjers; 28. Motala Kanaljorden; 29. Motala Strandvägen; 30. Prestemoen 1; 31. Viste cave; 32. Aflo. The dotted line indicates the border between North European (D-method) and North-East European (Z-method) bone technology for slotted bone tool production ca. $9500-8000$ cal BP according to Bergsvik and David (2015)

related to the composite slotted bone tool technology in northern Europe and the East European Plain is strongly hampered by the suboptimal preservation of organic material, as well as a preference to date layers instead of implements, which has resulted in a scarcity of well-dated inset bone tools.

Until recently, a very limited number of sites with more or less securely dated inset bone tool contexts has been reported from the vast area stretching from the Scandinavian Peninsula to the Moscow region in the east (Knutsson et al., 2016). However, with the addition of 13 slotted tools from Strandvägen and Kanaljorden sites in Motala, Sweden (Gummesson \& Molin, 2019), as well as direct dates on the slotted points from Vaikantonys and Obšrūtai in Lithuania (Ivanovaitè et al., 2018), the slotted knife from Ulbi, Estonia (Bjørnevad et al., 2019) and a slotted point from an unknown location in the southeastern Baltic (Philippsen et al., 2019), the chronological position of inset bone tool technology in the area is becoming more robustly constrained, yet even this 
improved chronological lattice makes it difficult to evaluate whether slotted bone technology using standardized microliths should be seen as an adaptive response to specific climatic/environmental conditions, or whether it is carried to Northern Europe as part of a demic diffusion, or possibly both.

In this paper, we present a set of additional direct dates from slotted tools deriving from Central Russia, Belarus, Estonia and Poland. We combine the new information with previous, secure dates of composite slotted tools in the area to arrive at a better understanding of the timeframe within which the technology was in use, and on this basis to discuss aspects related to the organization of slotted inset bone tool technology vis-à-vis culture-historical, climatic and environmental drivers. Against this dramatically improved empirical backdrop, we suggest that neither single environmental drivers nor cultural preferences explain the use of slotted bone tool technology alone. Instead, the composite nature of slotted bone tool technology means that it is affected by a diverse suite of organizational and cultural drivers, the strength and downstream correlates of which may be strongly situational and therefore not duplicated in other regions even if seemingly similar composite technologies were in use.

\section{Material and Methods}

All dates in our ${ }^{14} \mathrm{C}$ dating program were obtained on pitch glue sampled from slots of inset tools or, in two cases, from pitch glue on the distal end of the implement where a haft was originally attached. Pitch glue was considered a better material for dating than bone collagen for two reasons:

1) The less than $10 \mathrm{mg}$ sample required in dating pitch glue (equivalent in dimensions to the ball head of a common sewing pin) is considerably smaller than the up to $1000 \mathrm{mg}$ of bone needed for dating bone collagen. This makes dating pitch glue a markedly less intrusive method.

2) Analyses conducted on the black substance used to glue insets to slotted points, as well as for other purposes in northern Europe during the Mesolithic, suggest the use of birch bark pitch (Bjørnevad et al., 2019; Edgren, 1997; Vahur et al., 2011), while the osseous material used to produce slotted bone tools in the area seems to derive from large terrestrial ungulates (David, 2009), for which a reservoir effect may in some cases be possible (Philippsen, 2019), birch bark pitch, with tar produced from the outer layer of short-lived Betula ssp. as its main component, can be expected to have a very limited age of its own.

We had the possibility to sample and date 17 previously undated inset bone tools from the study area for this study (Table 1, Fig. 2). All samples were dated in the Aarhus AMS Centre (Department of Physics and Astronomy, Aarhus University) and the results calibrated using the OxCal 4.4.2 program (base year 1950; Bronk \& Ramsey, 2020) and the IntCal 20 calibration curve (Reimer et al., 2020). We targeted specimens with enough preserved pitch glue to enable sampling without depletion, targeting sites and areas from which no dates of inset tools existed. For the purpose of comparison, we also dated one bone harpoon from Zamośtje 5, layer IX, where lithics belonging to the 
Table 1 The sampled implements. The measurements indicate the size of the osseous part of the inset tools and harpoon in their present state. See Fig. 2 and SI 1 for photographs of all the artefacts in the table

\begin{tabular}{lllllll}
\hline Country & Location & Nr. & L $(\mathrm{mm})$ & W $(\mathrm{mm})$ & $\mathrm{T}(\mathrm{mm})$ & Slotting \\
\hline Russia & Karacharovo & & 102 & 10 & 5 & Unilateral \\
Russia & Minino 2 & Y2: 1 & 98 & 29 & 10 & Bilateral \\
Russia & Minino 2 & Y5: 114 & 85 & 18 & 8 & Bilateral \\
Russia & Minino 2 & Y5: 123 & 108 & 23 & 7 & Bilateral \\
Russia & Minino 2 & Y5: 152 & 64 & 19 & 10 & Bilateral \\
Russia & Minino 2 & Y5: 172 & 202 & 25 & 15 & Unilateral \\
Russia & Minino 2 & Y5: 193 & 295 & 32 & 11 & Bilateral \\
Belarus & Aziarnoje 2B & KP 5773: VP 373 & 93 & 6 & 4 & Bilateral \\
Belarus & Aziarnoje 2B & KP 5788: VP 399 & 214 & 8 & 6 & Bilateral \\
Belarus & Aziarnoje 2B & KP 5788: VP 403 & 171 & 12 & 7 & Bilateral \\
Belarus & Michnievičy & & 145 & 30 & 18 & Unilateral \\
Estonia & Lammasmägi & AI 3359: 172 & 90 & 33 & 7 & Bilateral \\
Estonia & Lammasmägi & AI 3359: 189 & 125 & 25 & 7 & Bilateral \\
Estonia & Lammasmägi & AI 3410: 561 & 117 & 23 & 5 & Bilateral \\
Estonia & Pärnu River & AI 2761: 5 & 128 & 10 & 7 & Unilateral \\
Estonia & Pärnu River & AI 2761: 6 & 151 & 11 & 8 & Unilateral \\
Poland & Tłokowo & MMA 1730 & 186 & 13 & 5 & Bilateral \\
Russia & Zamośtje 5 & Zam 5: 74 & 222 & 10 & 7 & No slot \\
\hline
\end{tabular}

Resseta culture suggested an early context with good preservation of organic material but devoid of slotted bone tool technology. To test the reliability of pitch glue in radiocarbon dating, in one case (Minino 2, Y5: 193; Fig. 2h), two separate samples were dated from the same implement, one from a slot and a second from the hafting glue.

\section{Sites and Sampled Tools}

Karacharovo (Vladimirskaja Oblast, Murom, Russia) The Karacharovo sample derives from a fragment of a unilaterally slotted bone point with flint insets. The point is a stray find made by a resident of the village of Karacharovo in 2016 and brought to the Murom Regional Museum of Local Lore, from which it was delivered to the Institute of Archaeology (Moscow) by V.V. Beylekchi. It originates from the mouth of the Karacharov ravine, in the upper part of which was located the Terminal Paleolithic Karacharov site, excavated in the late nineteenth century by Count A.S. Uvarov (1881). The site appears to have been lost to time as recent surveys have not been able to locate it (Trusov, 2011). It was nevertheless considered probable that the slotted point originally derived from the Paleolithic site.

Minino 2 and Zamośtje 5 (Moscowskaja Oblast, Sergievo-Posad Region, Russia) The complex geo-archaeological site Minino 2 is located adjacent to the Dubna River in the area of the Zabolotsky peat bog. The site consists of multiple 


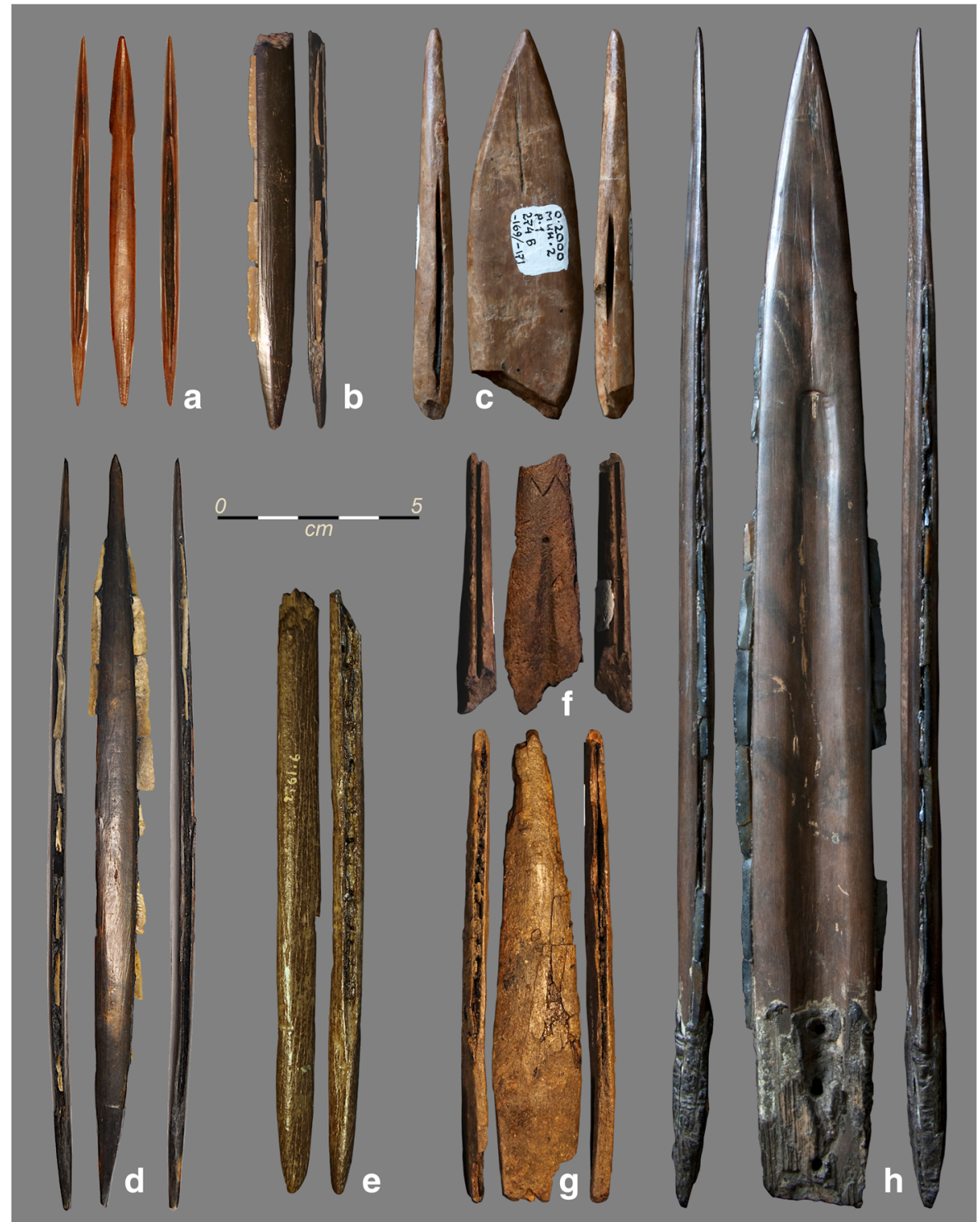

Fig. 2 Examples of slotted bone tools dated in our dating program to ca. 15700-7300 calBP. a Aziarnoje 2B/ KP 5773: VP373; b Karacharovo; c Minino 2/Y2:1; d Tłokowo/MMA 1730; e Pärnu River/AI 2761:6; f Minino 2/Y5:152; g Kunda Lammasmägi/AI 3410:561; h Minino 2/Y5:193. See Supplementary information 1 for photographs of all the implements dated for this study. Photo D courtesy of J. Orłowska

layers of Stone Age occupation and a set of burials, forming a complex palimpsest that has evidently been conditioned by various natural and cultural processes affecting the soil profile from the Late Pleistocene onwards, as well as the digging of burials through earlier layers. In addition, processes related to modern peat extraction in the Zabolotsky bog area have also significantly altered the site. 
Excavations at Minino 2 have been conducted during ten field seasons in the years 1997-2019 in a total area of about $600 \mathrm{~m}^{2}$ (Gracheva et al., 2006; Nikolaev et al., 2002; Sorokin, 2000, 2007, 2009, 2010, 2011, 2013, 2016; Sorokin \& Hamakawa, 2014; Sorokin et al., 2018). The finds consist of ca. 25,000 lithic items, of which approximately 4000 show secondary processing, ca. 8500 fragments of osseous material including over 600 bone and antler implements and fragments thereof, as well as other finds including small fragments of Neolithic-Bronze Age pottery in the upper cultural layer.

The lower cultural layer in the main occupation area of the site consists of two horizons. In the upper horizon, there are artefacts of the Zadnepilevo Mesolithic culture (ca. 10,000-8500 cal BP), while the lower horizon contains artefacts of the long-lived Resseta culture generally considered a Terminal Paleolithic archaeological culture (ca. 15,800-12,000/11,500 cal BP; Sorokin et al., 2018). On the shore slope and in river sediments in front of the site, finds of diverse cultural and chronological settings were found in water-deposited layers rich in organic matter separated by sterile strata (Sorokin, 2009, 2010, 2011; Sorokin \& Hamakawa, 2014; Sorokin et al., 2018, 2019). Two of the slotted implements selected for this study originate from the lower occupation layer of the site (Y2: 1 and Y 5: 123) and four from the sloping shore layers (Y5: 114, :152, :172 and :193).

Zamośtje 5 is also a site with well-preserved organic material. It is located ca. 50$100 \mathrm{~m}$ from Minino 2 on the opposite bank of the Dubna River. Zamośtje 5 has yielded no finds of inset bone tools, although a rich assemblage of artefacts made of organic material has been retrieved. The site has a stratigraphy consisting of nine cultural layers and burials (Sidorov \& Sorokin, 1997, 1998, 2000, 2001; Sorokin, 2000, 2009; Sorokin \& Hamakawa, 2014; Sorokin et al., 2018). A harpoon head of osseous material found in the stratigraphically lowest layer (layer IX, nr. 74) containing also lithic implements of the Terminal Paleolithic Resseta culture was selected for dating.

Aziarnoje 2B (Liubań District, Belarus) An assemblage of more than 120 bone and antler artefacts was salvaged from the underwater site Aziarnoje 2B located in Lake Viačera, central Belarus. The artefacts were lifted up from the lakebed in the course of commercial sapropel extraction and collected by archaeologist Mikalai Kryvaltsevich in 1985-1991 (Kryvaltsevich, 1996, 2008; Kryvaltsevich \& Simakova, 2004). A number of prehistoric sites are known around Lake Viačera. The rich Stone and Bronze Age site Aziarnoje 2A is located on the shore next to the underwater area Aziarnoje 2B. In addition, the Aziarnoje 1 site is located on a sandy promontory a few hundred meters to the northwest of Aziarnoje 2B. Excavation and controlled surface collection at Aziarnoje 1 yielded evidence of activity beginning in the Terminal Paleolithic and continuing all the way through the Iron Age (Kryvaltsevich, 1999). Alongside with finds from other periods, a representative lithic assemblage of the Mesolithic Kudlaivka culture, as well as some flint finds associated with the Terminal Paleolithic Swiderian culture, derives from here (Kudrashou \& Kryvaltsevich, 1994; Kudrashou, 1997).

The lakebed assemblage from Aziarnoje 2B includes items of various morphological and functional types such as points, arrowheads, harpoons, daggers, adzes and mattocks. On typological grounds, Kryvaltsevich (1996) associates the finds with various cultural units of the Mesolithic and Neolithic. In addition to the osseous material, nearly 1150 other archaeological finds were collected: ca. 1100 potsherds of 
the Neolithic and Early Bronze Age, a small flint inventory including two Swiderian tanged points and a number of non-worked animal bones and pieces of osseous material. Kryvaltsevich suggests that the Mesolithic implements made their way into the lakebed in the course of hunting, fishing or other activities by the lakeside, whereas the later artefacts may derive from pile-dwellings or possibly from a site submerged during a later transgression. Three bilaterally slotted points kept at the Liubań Museum of People's Glory (KP 5773: VP 373, KP 5788: VP 399 and KP 5788: VP 403) were dated from the Aziarnoje 2B assemblage.

Michnievičy (Smarhoń District, Belarus) From the 1970s through the 1990s, a rich paleontological and archaeological collection was recovered from the site of Michnievičy (also known as Smarhon quarry) near the town of Smarhon in the middle reaches of the Vilija River. Nearly 7000 animal bones and antlers, including more than 100 worked pieces and implements, were collected from floodplain deposits in the course of sand and gravel quarrying. On typological grounds, the finds date from the Mesolithic and the Neolithic (Charniauski, 1992, 2006; Charniauski \& Kalinouski, 1972; Kalinouski, 1983, 1995; Malyutina et al., 2019). A flat unilaterally slotted bone spearhead from Michnievičy, kept in the Institute of History of the National Academy of Sciences of Belarus, was sampled for this study.

Kunda Lammasmägi (Estonia) The iconic settlement site of Kunda Lammasmägi is located on a small hilltop in northeastern Estonia, a location that during the Mesolithic was an island in the Kunda paleolake (Sander \& Kriiska, 2018). Following the discovery of the site in 1886, numerous archaeological excavations have taken place and a large number of artefacts, including multiple items made of bone and antler, have been found (Åkerlund et al., 1996; Grewingk, 1882, 1887; Indreko, 1936, 1948; Jaanits, 1965; Sander \& Kriiska, 2015). Some items of osseous material have also been collected from the sediments of the ancient lake that surround the settlement.

The cultural layer of the settlement that in places reaches a thickness of approximately $1 \mathrm{~m}$ developed over a long period of time and has been extensively mixed by various natural and cultural processes. It contains finds from a timespan extending from the Early Mesolithic to the end of the Neolithic, with twelve radiocarbon dates between 10,700 and 3700 calBP (Sander \& Kriiska, 2018). In addition, a small number of loose human bones have been found from the Kunda Lammasmägi site (Tõrv, 2018). Three bilaterally slotted implements (fragmented knives/daggers) stored at the Archaeological Research Collections of the Tallinn University (AI 3359: 173, AI 3359: 189 and AI 3410: 561) were dated from the site in this study.

Pärnu River (the Lower Reaches of River Pärnu, Estonia) During the first decades of the twentieth century, nearly 2000 archaeological finds, mostly objects of bone and antler, were collected from the lower reaches of River Pärnu, southwestern Estonia (Bliebernicht, 1924; Glück, 1906; Indreko, 1926). All artefacts derive from a $1.5 \mathrm{~km}$-long stretch of the river and were salvaged in the course of sand and gravel quarrying. No in situ finds or cultural layers were reported. Two antler objects from this collection have previously been dated - a sculpture of a bird to ca. $7880 \mathrm{cal} \mathrm{BP}$ (Jonuks, 2013) and a human figurine to ca. 7990 cal BP (Jonuks, 2016). On typological grounds, most finds from the riverbed would be expected to date from the Early Mesolithic to the Neolithic, while the youngest finds are from the Middle Ages. 
It is probable that the finds from Pärnu River derive from several Stone Age sites originally located on the banks of the River Pärnu but inundated and buried under marine sediments by the rising transgressive Littorina Sea around 7500-7300 cal BP (Nirgi et al., 2019; Rosentau et al., 2011). On the basis of reported human bones (Glück, 1906, 275), a cemetery may also have been buried under the sediments (Tõrv, 2018, 242). Unfortunately, the human bones that were collected during the sand and gravel quarrying in the early twentieth century can no longer be located. Two broken unilaterally slotted points/knives from the Pärnu River collection stored at the Archaeological Research Collections of the Tallinn University (AI 2761: 5 and AI 2761: 6) were dated.

Tłokowo (Poland) The Tłokowo slotted bone point was found accidentally in 1989 while digging a cattle pond in the village of Tłokowo (north-east part of Poland). It was retrieved from a depth of approximately $0.8-1 \mathrm{~m}$ below the present-day ground level, in the bottom part of a layer of brown peat (Sulgostowska \& Hoffman, 1993). The discovery of the artefact resulted in six seasons of excavation at the site, managed by Romuald Schild of the Archaeology and Ethnology Institute of the Polish Academy of Sciences (PAN) in Warsaw (Schild et al., 2003). Several settlement horizons were distinguished at the site, although in strata assigned to the Horizon IV, which yielded the point selected for dating in this study, only a limited number of finds were present (Schild et al., 2003).

The bilaterally slotted Tłokowo point was made using a piece of radial bone from a large herbivore, most likely a red deer or European elk (Alces alces). The 16 preserved flint insets are made of chalk flint, and using an X-ray image, typologically classified as 4 Borki-type blades, 8 triangles and 4 likely triangles (Sulgostowska \& Hoffman, 1993).

The chronological position of the Tłokowo point was earlier determined on the basis of contextual analyses, typological inference vis-à-vis the flint insets and direct radiocarbon dates obtained from peat layers. As a result, the artefact was assigned to the Kunda complex and dated to the Preboreal (Schild et al., 2003; Sulgostowska \& Hoffman, 1993). Based on the same premises, some researchers shifted the relative age forward to the Boreal period, dating it to ca. 9300 cal BP (Hartz et al., 2010). Currently, the point is in the collection of the Archaeology Department of the Museum of Warmia and Mazury in Olsztyn (inv. no. MMA 1730). Recently, a separate paper on the Tłokowo point, including the radiocarbon date from this dating program, has already been published (Osipowicz et al., 2020).

\section{Other Radiocarbon Dates and Summed Probability Distributions}

In order to draft a more comprehensive picture, we also gathered all readily available radiocarbon dates from the study area with a secure connection to slotted bone tools (closed contexts, see SI 2). We divided the dates into three classes according to their evidential strength in relation to dating inset bone tools: (1) direct date of pitch or collagen, (2) date from a closed context (burials) and (3) short-term site contexts i.e. contextual dates from excavation units that suggest a relatively short period of formation. Contexts containing only microliths/microblades were consequently left outside of this study, as were dates from slotted bone tool-bearing horizons/layers showing long 
accumulation spans. Corrections for reservoir effect were applied according to the original publications, and where possible, dates on terrestrial animal bone and bast were preferred over dates on human bone and pine bark from the same context. We then used the radiocarbon data to interrogate the temporal distribution of slotted bone tool use in the study area by calculating three summed probability distributions (SPD) based on the radiocarbon date classification (SPD-A: classes 1, 2 \& 3, SPD-B: classes 1 \& 2, and SPD-C: class 1) employing the Sum function in OxCal 4.4.2 (Bronk \& Ramsey, 2020). Dates for SPD-A and SPD-B were aggregated per context using a 200year bin size combining all dates within a bin with the $R$ _Combine function of the same program, to represent a single date in the SPD. Finally, we visually compared the SPD:s to the NGRIP $\delta^{18} \mathrm{O}$ data and local temperature proxy curves from the studied region to detect possible correlations between temperature and slotted bone tool use (Fig. 3).

\section{Results}

Radiocarbon dating results are presented in Table 2. The success rate of pitch dating was high with 18 of the 19 samples sent for dating yielding results deemed reliable based on the find context. The two dates made separately on pitch deriving from the hafting mechanism and the slot of Minino 2 Y5: 193 are near-identical, suggesting that birch bark pitch samples give consistent and reliable results.

The summed probability distributions SPD-A, SPD-B and SPD-C are plotted in Fig. 3 together with four temperature reconstructions: the NGRIP $\delta^{18} \mathrm{O}$ temperature proxy data and three pollen-based reconstructions from the study area. The radiocarbon dataset resulted in 61 dates in 45 bins from 31 sites in SPD-A and 47 dates in 36 bins from 22 sites in SPD-B. In SPD-C, every date represents a single directly dated artefact, with two dates from the same artefact combined in only one case, resulting in 38 cases from 39 dates. In Fig. 4, the dates are represented in a geographical (west-east) order to illustrate their spatio-temporal positioning.

\section{Discussion}

Some of the earlier assumptions concerning the chronological position of the sampled implements were shown to be questionable by the radiocarbon dates presented here (Table 3). Most markedly, the Karacharovo point and the harpoon from Zamośtje 5, assumed to date to the Late Pleistocene, turned out to date to the Early Holocene, while the Tłokowo point, earlier assigned to the Early Holocene, turned out to belong to the Late Holocene. These results are not contradicted by the find contexts, as the Karacharovo point is a stray find and the discrepancies between contextual and radiocarbon dates in the case of Zamośtje 5 and Tłokowo are easily explained by later deposition into lacustrine/riverine sediments.

Together with the other radiocarbon dates on inset bone tool technology in the studied area (our categories 1-3, SI 2), the new dates demonstrate substantial longevity of the technological concept in northern Europe and the East European Plain. The Late Pleistocene dates from Minino 2 are the earliest for inset bone implements in this part of Europe, but in the same broad timeframe as the inset technology of the Eastern 


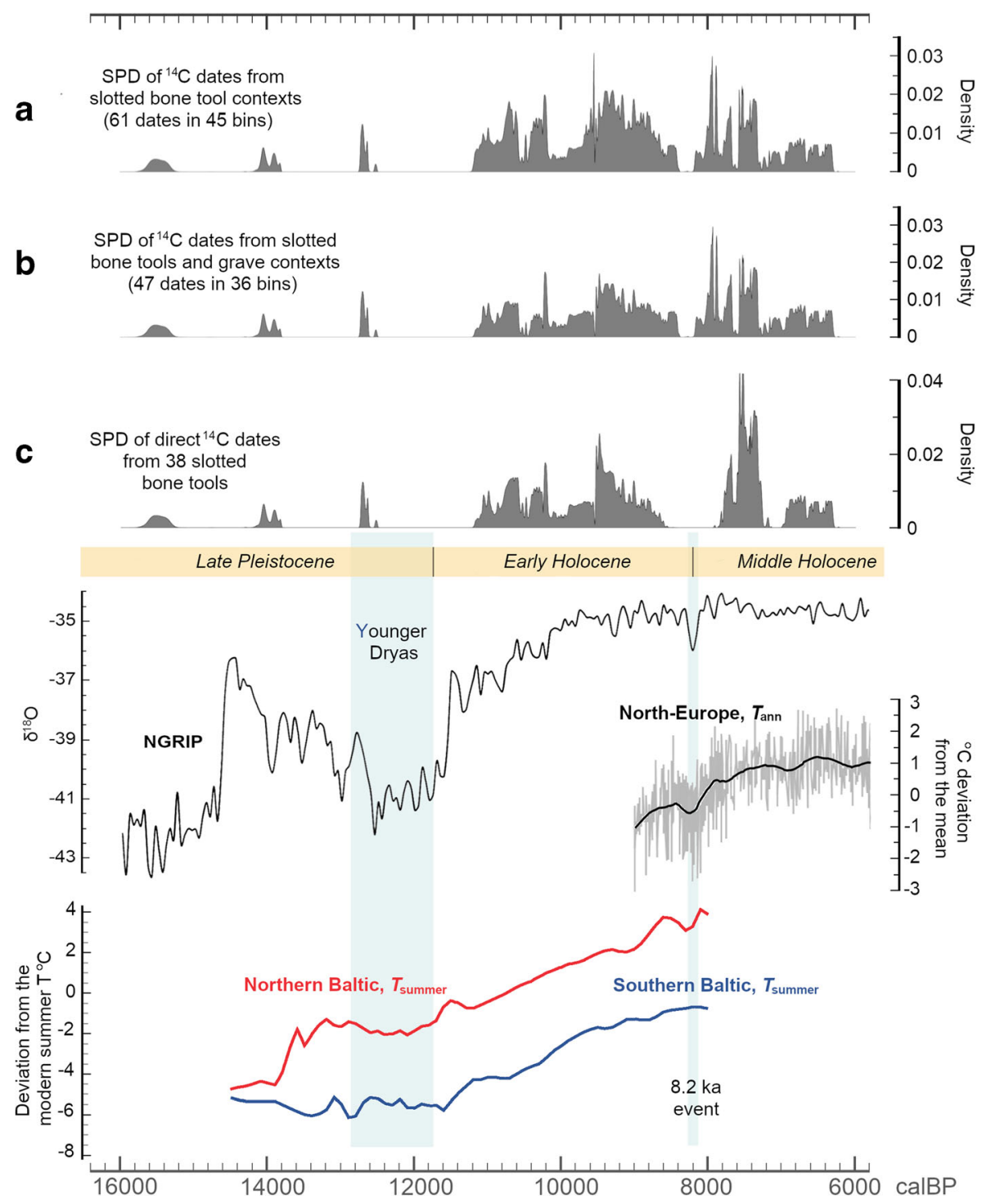

Fig. 3 Top, summed probability distributions of radiocarbon dates from the study area: a directly radiocarbondated slotted bone tools and radiocarbon-dated slotted point contexts aggregated per context using a 200-year bin size (SPD-A); b directly dated slotted points and grave contexts aggregated per context using a 200-year bin size (SPD-B); and C) directly dated (pitch or collagen) slotted bone tools. Bottom: NGRIP $\delta^{18} \mathrm{O}$ variation (Rasmussen et al., 2006), North-European pollen-based stacked annual mean temperature record (Seppä et al., 2009), and polled-based reconstructions of summer temperatures in the Northern Baltic (Estonia \& Latvia) and Southern Baltic (Belarus \& Lithuania) regions (Veski et al., 2015). The borders between Late Pleistocene and Early and Middle Holocene are indicated according to the International Commission of Stratigraphy Chronostratigraphic Chart (www.stratigraphy.org). See SI 2 for data used to form the SPDs

Gravettian of the Russian Plain (Amirkhanov, 1998; Amirkhanov et al., 2009; Praslov \& Rogachev, 1982), early finds of slotted bone tools from western Siberia (e.g. Abramova, 1984; Abramova et al., 1991; see also Knutsson et al., 2016), and 
Table 2 The radiocarbon dating results. Map = site number in Fig. 1

\begin{tabular}{|c|c|c|c|c|c|c|c|c|}
\hline Country & Site & Number & Lab. code & Date & \pm & cal BP & Median & Map \\
\hline \multicolumn{9}{|c|}{ Slotted (inset) bone tools } \\
\hline Russia & Minino 2 & Y2: 1 & AAR-27604 & 12946 & 61 & $15721-15250$ & 15473 & 2 \\
\hline Russia & Minino 2 & Y5: 123 & AAR-27607 & 12115 & 58 & $14135-13782$ & 13997 & 2 \\
\hline Russia & Minino 2 & Y5: 114 & AAR-27603 & 10653 & 47 & $12708-12553$ & 12631 & 2 \\
\hline Russia & Minino 2 & Y5: 172 & AAR-26567 & 9613 & 50 & $11169-10768$ & 10944 & 2 \\
\hline Belarus & Aziarnoje 2B & KP 5773: VP 373 & AAR-28506 & 9545 & 37 & $11086-10710$ & 10926 & 9 \\
\hline Russia & Karacharovo & - & AAR-26569 & 9485 & 35 & $11068-10590$ & 10734 & 1 \\
\hline Russia & Minino 2 & Y5: 193 (slot) & AAR-26568 & 9206 & 35 & $10491-10253$ & 10358 & 2 \\
\hline Russia & Minino 2 & Y5: 193 (handle) & AAR-27606 & 9173 & 43 & $10486-10237$ & 10333 & 2 \\
\hline Russia & Minino 2 & Y5: 152 & AAR-27605 & 9200 & 45 & $10496-10247$ & 10357 & 2 \\
\hline Belarus & Aziarnoje 2B & KP 5788: VP 399 & AAR-28507 & 9026 & 41 & $10251-9972$ & 10209 & 9 \\
\hline Estonia & Lammasmägi & AI 3359: 173 & AAR-26570 & 8789 & 50 & $10146-9601$ & 9814 & 15 \\
\hline Estonia & Lammasmägi & AI 3359: 189 & AAR-27602 & 8455 & 40 & $9532-9429$ & 9483 & 15 \\
\hline Estonia & Lammasmägi & AI 3410: 561 & AAR-26571 & 8446 & 48 & $9537-9325$ & 9475 & 15 \\
\hline Belarus & Aziarnoje 2B & KP 5788: VP 403 & AAR-28508 & 8255 & 42 & $9405-9090$ & 9235 & 9 \\
\hline Estonia & Pärnu river & AI 2761: 5 & AAR-26573 & 8252 & 41 & $9404-9040$ & 9229 & 14 \\
\hline Estonia & Pärnu river & AI 2761: 6 & AAR-26572 & 8018 & 49 & $9023-8662$ & 8881 & 14 \\
\hline Poland & Tłokowo & MMA 1730 & AAR-27601 & 6492 & 38 & $7472-7320$ & 7397 & 11 \\
\hline Belarus & Michnievičy & - & Unsuccessful & & & & & 10 \\
\hline \multicolumn{9}{|c|}{ Harpoon head } \\
\hline Russia & Zamośtje 5 & Zam 5: 74 & AAR-27608 & 8724 & 52 & $9890-9550$ & 9690 & 4 \\
\hline
\end{tabular}

Magdalenian sites characterised by composite tools with insets in western Europe (e.g. Langlais et al., 2015), as well as the Asian microblade industries associated with slotted bone tools (e.g. Elston \& Brantingham, 2002).

The results also lend strength to the notion that most of the slotted points from northern Europe and the East European Plain are linked to the rapid Early Holocene climatic warming and its downstream environmental correlates. This result warns against causally linking microblade use and slotted inset bone tools to increased environmental pressure from climatic cooling without closer analysis. In fact, the broad correlation of the dates with the haphazard warming trend beginning at around 16,000 cal BP after the end of the Last Glacial Maximum would instead suggest that this kind of technological constellation may be linked to warmer, wetter and more forested environments, or to risks generated by changing environmental regimes independently of whether such change is towards colder or warmer situations. By the same token, do note also the clear gap in the SPDs coinciding with the 8.2 ka cold event that caused a 200 year-long cold snap in the study area and beyond (e.g. Seppä et al., 2009), although at this point, any possible causal relationship between the lack of dates and the cold event remains to be demonstrated.

The early dates from Minino 2 indicate that inset bone tools were already in use in the Moscow region when Norway, Finland, most of Sweden and Estonia were still covered by the Scandinavian Ice Sheet. Their use continued in this region at least into 


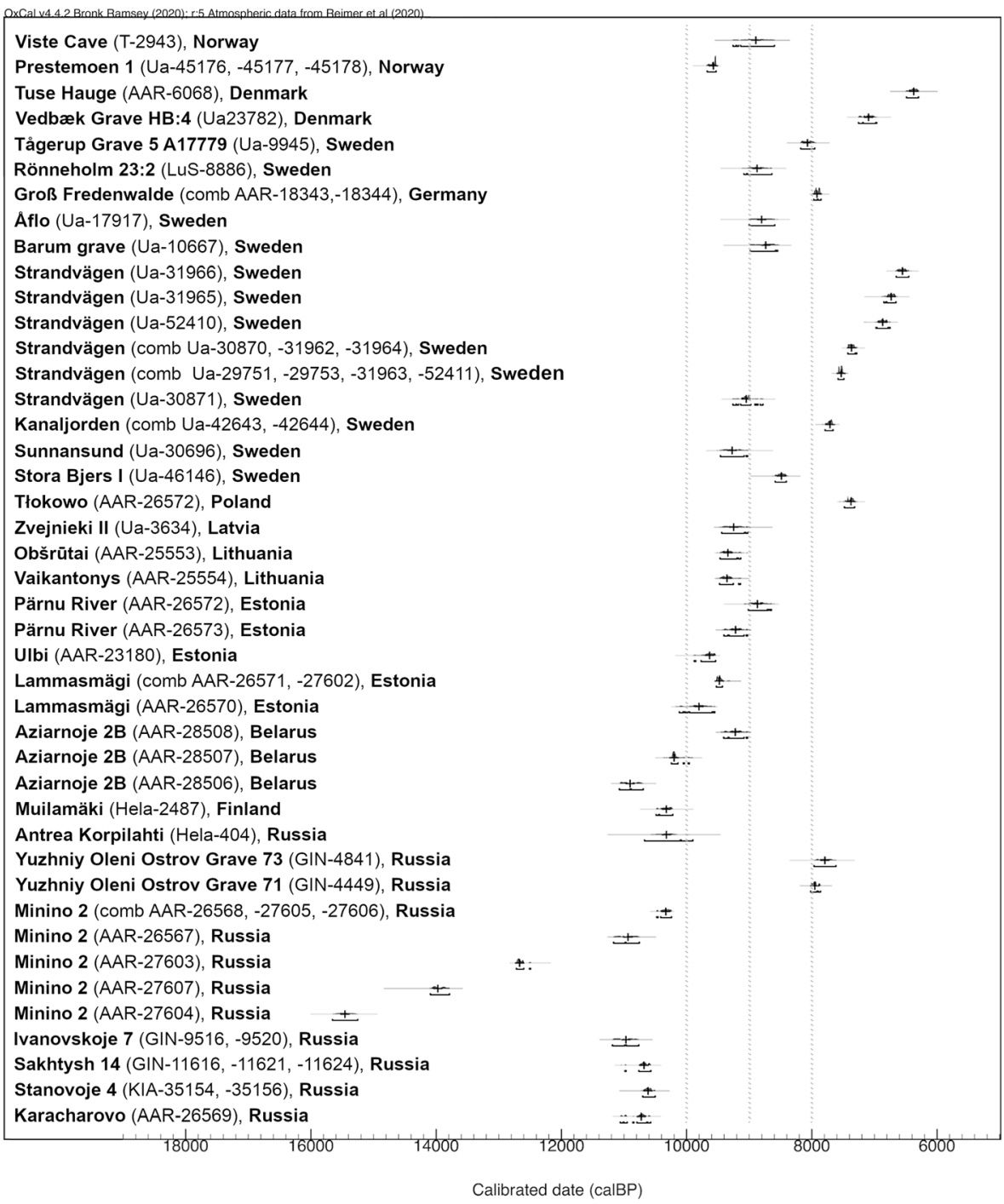

Fig. 4 Calibrated radiocarbon date plots (normalized areas) of slotted point contexts and stray find slotted points in the study area ordered according to the longitudinal coordinate of the find location. Data from Apel et al. (2017), Bergsvik \& David (2015), Bjørnevad et al. (2019), Brinch Petersen (2015), Edgren (1997), Eriksson et al. (2003), Gummesson \& Molin (2019), Gurina (1956), Hartz et al. (2010), Ivanovaite et al. (2018), Jungklaus et al. (2016), Jussila et al. (2012), Kjällquist (2001), Kjällquist et al. (2016), Larsson (2005), Miettinen et al. (2008), Oshibkina (1989), Persson (2014), Philippsen et al. (2019), Sjöström \& Hammarstrand Dehman (2010), Skakun et al. (2011), Sten et al. (2000), Vang Petersen (2001), Zaretskaya et al. (2005), and this study. See SI 2 for radiocarbon dates and coordinates

the local Final Mesolithic period (ca. 7900-7700 cal BP) that marks the end of inset bone tool use at the Zamośtje 2 site, located in the vicinity of Minino 2 and Zamośtje 5 (Lozovskaya \& Lozovski, 2013).

In light of earlier data and the new radiocarbon dates, and despite the mostly unfavorable soil conditions for the preservation of osseous materials, slotted point 
Table 3 The expected chronological position (CP) of the radiocarbon-dated slotted tools against their verified chronological position according to the radiocarbon dates. LP= Late Pleistocene, EH= Early Holocene, $\mathrm{MH}=$ Middle Holocene. See Fig. 3 for chronological division

\begin{tabular}{lllll}
\hline Site & Number & Expected CP & C14 / cal BP & CP after C14 \\
\hline Karacharovo & - & LP & $11068-10583$ & EH \\
Minino 2 & Y2: 1 & LP/EH & $15679-15274$ & LP \\
Minino 2 & Y5: 114 & LP/EH & $12734-12505$ & LP \\
Minino 2 & Y5: 123 & LP/EH & $14135-13782$ & LP \\
Minino 2 & Y5: 152 & LP/EH & $10496-10247$ & EH \\
Minino 2 & Y5: 172 & LP/EH & $11177-10765$ & EH \\
Minino 2 & Y5: 193 & LP/EH & $10487-10248$ & EH \\
Zamośtje 5 & Zam 5: 74 & LP & $9893-9546$ & EH \\
Aziarnoje 2B & KP 5773: VP 373 & EH/MH & $11084-10701$ & EH \\
Aziarnoje 2B & KP 5788: VP 399 & EH/MH & $10250-9965$ & EH \\
Aziarnoje 2B & KP 5788: VP 403 & EH/MH & $9414-9031$ & EH \\
Lammasmägi & AI 3359: 173 & EH & $10124-9557$ & EH \\
Lammasmägi & AI 3359: 189 & EH & $9537-9421$ & EH \\
Lammasmägi & AI 3410: 561 & EH & $9538-9321$ & EH \\
Pärnu river & AI 2761: 5 & EH & $9410-9031$ & EH \\
Pärnu river & AI 2761: 6 & EH & $9019-8650$ & EH \\
Tłokowo & MMA 1730 & EH & $7481-7316$ & MH \\
\hline
\end{tabular}

use is now detected in the Eastern Baltic region and Belarus almost throughout the Early Holocene, ca. 11,000-8000 calBP, with the earliest slotted tools in Russian and Finnish Karelia contextually dated to ca. $10,800-10,400$ cal BP, i.e. to the Early Holocene pioneer colonisation phase in Karelia (Kriiska et al., 2016; Rostedt \& Kriiska, 2019). Later use is indicated by the two points dated to Middle Holocene from south-eastern Baltic, as well as slotted implements found in graves in Yuzhniy Oleni Ostrov (Russian Karelia), dated to ca. 8000-7600 cal BP (see also Schulz, 1996 for a possible late find from Finland).

In southern Scandinavia, the use of slotted bone tools seems to peak late, in the local Middle Mesolithic Kongemose culture, ca. 8400-7400 cal BP (Sørensen, 2017). To this period belong also three other slotted tools from southern and south-eastern Baltic, the Tłokowo point, a contextually dated dagger from Groß Fredenwalde (Germany) and a directly dated slotted point from an unknown find location in S-E Baltic. An exception to the relatively late dates is the stray find point reported by a seller of antiquities in the early 1800s to have been found near Wiesbaden in Germany, and dated to the Early Holocene (10,180-9690 cal BP, see SI 2). Unfortunately, the other slotted implements found in Poland and Germany i.e. slotted tools reported from German museum collections in the late nineteenth century and linked by Friedel (1872) to the Swedish and Danish Kongemose finds, and the ten slotted points found prior to WW2 from Poland but destroyed during the war remain undated.

The earliest dates of slotted inset artefacts thus are from the eastern part of the study area, corresponding to the model that people and technological concepts dispersed from 
the East European Plain - perhaps ultimately from the Far East - towards the west in the early Postglacial, and that this dispersal had a major influence on the tool-kit composition of the northern European Early/Middle Mesolithic (e.g. Bergsvik \& David, 2015; Damlien, 2016; Günther et al., 2018; Kashuba et al., 2019; Knutsson et al., 2016; Manninen et al., 2021; Sørensen et al., 2013). However, resolving the issue of whether composite inset technology should primarily be seen as a local adaptive response to changing environmental conditions or as a culturehistorically contingent marker of particular communities or constellations of practice (cf. Stahl \& Roddick, 2016) demands a consideration of the wider technological context of their production and use.

Despite the long period of occurrence, chaîne opératoire analyses of Early and Middle Mesolithic bone tool technology in Europe indicate rather uniform ways (the so-called Z-method, Bergsvik \& David, 2015) of bone tool production, including slotted points, in most of the area discussed here ca. 9500-8000 cal BP. This suggests a shared ancestry in production methods, although such a perspective would also delineate a break or border in such traditions between the north-eastern sections of the study area and the area covering present-day Denmark and northern Germany (where the so-called D-method was in use; see Fig. 1; Bergsvik \& David, 2015; David, 2009). In marked contrast to the homogeneity suggested for technologies used to manufacture the osseous part of inset tools, the lithic blade and flake production technology that was used in the area during the Early Holocene was diverse, up to the point that, on the basis of lithic artefact typology, the record has been divided into a heterogeneous suite of archaeological cultures that supposedly occupied and evolved across northern Europe and the East European Plain (but see Reynolds \& Riede, 2019 for a recent critique of such definitions).

On a more general level, the insets used in slotted bone tools varied from backed blade segments and microblades on microcrystalline raw materials of good flakeability to macrocrystalline quartz flake fragments, the latter strategy considered advantageous when moving into regions scarce in tool-stone of suitable quality (e.g. Knutsson et al., 2016; Kriiska et al., 2016; Tsvetkova, 2017; see also Manninen \& Knutsson, 2014). However, core treatment practices show that on the eastern side of the Baltic Sea, Early Mesolithic reduction of flint and other high-workability tool-stone can be divided into three main strategies, consisting of conical or sub-conical blade core, narrow-face blade core and irregular core reduction (Hertell \& Tallavaara, 2011 and references therein). The conical blade core concept included intensive rejuvenation of the core platform, which resulted in constant reduction of blade length and width during the core reduction process and consequently to from up to $20 \mathrm{~cm}$ long blades to what can be called microblades (Sørensen et al., 2013). Its use seems to correlate with high mobility (Hertell \& Tallavaara, 2011). The narrow-face cores yielded blades of more uniform dimensions and can be considered a standardized serial production strategy suited especially for inset production (Hartz et al., 2010). The dataset analysed by Hertell and Tallavaara (2011) shows a rising trend for narrow-face core use between ca. 10,600 and 9600 cal BP in north-eastern Europe, after which the use of both conical and narrow-face blade reduction strategies seems to have markedly diminished in favour of flake production from irregular cores.

In Scandinavia and other parts of north-western Europe, the handle-core concept, dating to ca. 9000-7400 cal BP (Olofsson, 2002; Söderlind, 2018), is a reduction 
concept in many ways reminiscent of the serial bladelet production from narrow-face cores. Handle-core technology is also strongly linked to the use of inset bone tool technology (Larsson, 1990; Hartz et al., 2010). In this context, it is noteworthy that especially in Middle and Northern Sweden, the raw material for handle-cores was often macrocrystalline vein quartz (e.g. Molin \& Wikell, 2009), a raw material known to produce a large proportion of waste compared to, for instance, chert or flint (Tallavaara et al., 2010). Moreover, finds of slotted bone points with inset flakes and flake fragments of vein quartz in Sweden and Finland (Knutsson et al., 2016; Manninen et al., 2018; Pälsi, 1920) indicate that also a strategy utilizing insets produced as a part of flake core reduction was employed. Evidently, the inset raw material or the reduction methods used to produce the insets were not decisive elements in this technology in our study area, although future experimental work could substantiate to what degree inset standardization impacts function and re-tooling costs.

Tool and weapon systems in principle are costlier to produce the more parts and raw materials they require. It is often assumed, therefore, that in addition to durability provided by the osseous part of the composite tool, lithic organizational dimensions such as reliability (sensu Bleed, 1986) and efficiency through standardization, as well as intensification of lithic raw material use as a response to high mobility, were the main drivers for the adoption of inset bone tool technology (cf. Elston \& Brantingham, 2002). However, the variety of ways Early Holocene slotted bone tool technology and associated lithic technology was organized in northern Europe and the East European Plain suggests a much wider set of organizational and other dimensions linked to inset bone tool technology. Intensification of raw material use may very well have been one important dimension in serial production of blades, but the presence of the much more wasteful and generalized conical blade production, employing the same high-quality raw materials at the same sites, suggests that at least in these cases, the scarcity of raw material cannot be considered the main reason for inset production from narrow-face cores.

The rapidly warming Postglacial climate and the colonisation of previously uninhabited areas at the margins of the retreating Scandinavian Ice Sheet offer in our case the possibility to study the use and cultural evolution of a multicomponent technology in variable environments within a comparatively large area, and with an, at the time, shared history of material culture traits. Chatters (1987) regards human adaptation as a multidimensional mesh in which adaptive choices form separate axes intersecting in ways affected by a variety of interdependent choices. In such a view, the variability detected in lithic technology related to slotted implements on the one hand, and the relative uniformity of the slotted osseous parts of the composite tools on the other, can be considered adaptive choices operating within a framework of broadly shared cultural history.

The use of vein quartz for microblade production from handle-cores, as well as flake fragments of the same material, emphasises that although in many cases, probably interconnected, inset bone tool use, raw material selection and microblade production are components positioned on different axes of the mesh of organizational choicesand that these components, and the drivers for their combination in different situations, may have differed substantially between communities and even community members (Fig. 5). Organizational dimensions affecting the non-lithic parts of a composite tool affect also its lithic components. A composite tool therefore also implies a composition 


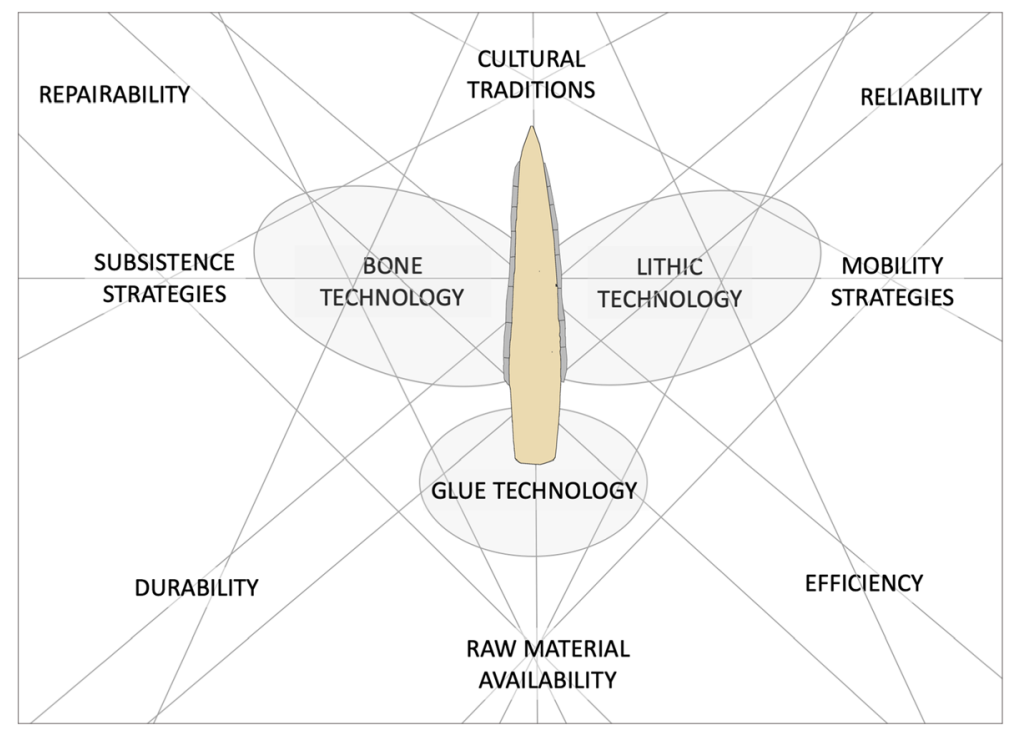

Fig. 5 Some dimensions in the $n$-dimensional mesh of technological choices affecting the use and manufacture of slotted bone tools in any given prehistoric situation. Many of these dimensions intersect separately in the different components of the composite tool, while at the same time, the locus of intersection in these separate technologies is also situational and affected by the whole

of organizational dimensions that are not necessarily in unison and that are not directly comparable to single-raw-material technologies. Such dimensions affecting the manufacture, use and repair of slotted bone tools are to be found, for example, in the restrictions affecting the design of the osseous part of the implement, the availability of suitable osseous raw materials and the availability and workability of adhesive materials, but also in the flexibility provided by the osseous support when selecting suitable lithic edge components.

We therefore argue that there is no one-to-one mechanistic link between microblade technology and slotted bone tools, suggesting that inset bone tool technology is a technological strategy that should not be considered an a priori extension of microblade technology, but rather as a technology in its own right, susceptible to situational variation, modification and evolution. Accepting this, its occurrence in diverse temporal and spatial settings (e.g. Abramova et al., 1991; Buvit \& Terry, 2011; Fedje et al., 2008; Helvig et al. 2008; Langlais et al., 2015; Okladniukov, 1950; Pétillon et al., 2011; Savchenko \& Zhilin, 2018; Tomasso et al., 2018; Tsvetkova, 2017; Zhilin, 2019) does not imply similarity in the associated lithic technology or environmental drivers.

\section{Conclusions}

In northernmost Europe and the East European Plain, the available data does not reveal a clearly defined trajectory leading to a superficially similar slotted bone tool technology. In fact, what the data suggest is that no single trajectory is there to be found, not in our study area, nor for the use of slotted tool technology in general. 
On the basis of our dating program and other radiocarbon dates, the earliest inset tools in our study area are of Late Pleistocene date, and a more or less continuous use can be tracked through the rapidly warming Early and Middle Holocene. During this time period, slotted bone tool technology is associated with a variable set of lithic core treatment practices and ways of inset production. Hence, explanations for the use of inset bone tools based on monolithic models of reliability, efficiency and the like ultimately fail. They do serve as robust starting points and end-members along the spectrum of technological choices that are actually faced and taken by prehistoric groups, but the pattern we see in our study area reveals historical specificity and path-dependence rather than clear patterns of selective or convergent evolution.

Although the data at hand do not allow tracing cultural transmission of the technology or continuity of cultural traditions, the spread of the technology to the west following the retreat of Scandinavian Ice Sheet, and its occurrence in the same area where also eastern Early Mesolithic blade production technology and lithic tool types spread during early Postglacial pioneer colonisation (Manninen et al., 2021; Sørensen et al., 2013) do suggest that knowledge of the technological concept in the area first arrived in the footsteps of the first pioneers from the east and was later transmitted and adopted with modifications in favourable circumstances, rather than re-invented multiple times.

Our results additionally suggest that a bottom-up approach is needed in order to understand why slotted bone technology and related microlith technology were used in different parts of the study area and beyond, as the reasons behind their use seem to be contingent, situational and variable. That said, evolutionary models and methods that seek to use the specific technological traits in parallel with notions of adaption (the tools of the so-called comparative method e.g. Collard \& Shennan, 2008; Mace \& Pagel, 1994; Manem, 2020; O’Brien et al., 2008) could be helpful in eventually more fully understanding the processes that shaped this technology.

Supplementary Information The online version contains supplementary material available at https://doi.org/ 10.1007/s10816-021-09517-7.

Acknowledgements We wish to thank the three anonymous reviewers for their valuable comments. This research was supported by The Research Council of Norway project no. 231305, the Estonian Research Council research project PRG243, the base financed project PHVAJ20919 of the Institute of History and Archaeology of the University of Tartu, the Centre of Excellence in Estonian Studies (TK145), the Russian Foundation for Basic Research (RFBR) projects \# 16-06-00078 (2016-2018) \& \# 19-09-00143 (2019-2021), the Independent Research Fund Denmark \#6107-00059B and National Science Center in Cracow (Poland) project no. 2016/23/B/HS3/00689.

Funding Open access funding provided by University of Helsinki including Helsinki University Central Hospital.

Open Access This article is licensed under a Creative Commons Attribution 4.0 International License, which permits use, sharing, adaptation, distribution and reproduction in any medium or format, as long as you give appropriate credit to the original author(s) and the source, provide a link to the Creative Commons licence, and indicate if changes were made. The images or other third party material in this article are included in the 
article's Creative Commons licence, unless indicated otherwise in a credit line to the material. If material is not included in the article's Creative Commons licence and your intended use is not permitted by statutory regulation or exceeds the permitted use, you will need to obtain permission directly from the copyright holder. To view a copy of this licence, visit http://creativecommons.org/licenses/by/4.0/.

\section{References}

Abramova 1984 = Абрамова, 3.А. (1984). Поздний палеолит Азиатской части СССР. In Борисковский, П.И. (Ed.), Палеолит СССР. (pp. 302-334). Археология СССР, І. Москва: Наука.

Abramova, et al. 1991 = Абрамова 3. А., Астахов С. Н., Васильев С. А., Ермолова Н. М. \& Лисицын Н. Ф. (1991). Палеолит Енисея. Ленинград: Наука.

Åkerlund, A., Regnell, M. \& Possnert, G. (1996). Stratigraphy and chronology of the Lammasmägi site at Kunda. In T. Hackens, S. Hicks, V. Lang, U. Miller \& L. Saarse (Eds.), Coastal Estonia. Recent Advances in Environmental and Cultural History (pp. 253-272). PACT 51. Rixensart: Pact Belgium.

Amirkhanov 1998 = Амирханов. Х.А. (Ed.), (1998). Восточный граветт. Москва: Научный мир.

Amirkhanov, et al. 2009 = Амирханов. Х.А.; Ахметгалеева, Н.Б., Бужилова, А.П., Бурова, Н.Д., Лев, С.Ю. \& Мащенко, Е.Н. (Eds.), (2009). Исследования палеолита в Зарайске 1999-2005. Москва: Зограф.

Apel, J., Wallin, P., Storå, J., \& Possnert, G. (2017). Early Holocene human population events on the island of Gotland in the Baltic Sea (9200-3800 cal. BP). Quaternary International, 465B, 276-286. https://doi.org/ 10.1016/j.quaint.2017.03.044.

Barton, L., Brantingham, P. J., \& Ji, D. (2007). Late Pleistocene climate change and Paleolithic cultural evolution in Northern China: implications from the Last Glacial Maximum. Developments in Quaternary Sciences, 9, 105-128. https://doi.org/10.1016/S1571-0866(07)09009-4.

Bergsvik, K. A., \& David, É. (2015). Crafting bone tools in Mesolithic Norway: a regional eastern-related know-how. European Journal of Archaeology, 18(2), 190-221. https://doi.org/10.1179/1461957114Y. 0000000073.

Bjørnevad, M., Jonuks, T., Bye-Jensen, P., Manninen, M. A., Oras, E., Vahur, S., \& Riede, F. (2019). The life and times of an Estonian Mesolithic slotted bone 'dagger'. Extended object biographies for legacy objects. Estonian Journal of Archaeology, 23(2), 103-125. https://doi.org/10.3176/arch.2019.2.02.

Bleed, P. (1986). Optimal design of hunting weapons. American Antiquity, 51(4), 737-747. https://doi.org/10. $2307 / 280862$.

Bliebernicht, E. G. (1924). Neue Funde aus dem Pernauflusse. Fundbericht von den J. 1920-1922. SMYAFFT, 34(2), 3-19.

Brantingham, P. J., Gao, X., Madsen, D. B., Bettinger, R. L., \& Elston, R. G. (2004). The initial upper Paleolithic at Shuidonggou, Northwestern China. In P. J. Brantingham, S. L. Kuhn, \& K. W. Kerry (Eds.), The Early Upper Paleolithic Beyond Western Europe (pp. 223-241). Berkeley: University of California Press.

Brinch Petersen, E. (2015). Diversity of Mesolithic Vedbcek. Acta Archaeologica, 86, 1.

Bronk, Ramsey, C. (2020). OxCal 4.4. Oxford Radiocarbon Accelerator Unit, Oxford

Burdukiewicz, J. M. (2005). Microlithic technology in the Stone Age. Journal of the Israel Prehistoric Society, 35, 337-351.

Buvit, I., \& Terry, K. (2011). The twilight of Paleolithic Siberia: humans and their environments east of Lake Baikal at the late-glacial/Holocene transition. Quaternary International, 242(2), 374 400. https://doi.org/ 10.1016/j.quaint.2011.05.003.

Charniauski, 1992 = Чернявский, M.M. (1992). Древнейшие роговые орудия из-под Сморгони. Lietuvos Archeologija 9, 116-120.

Charniauski 2006 = Чарняўскі, М.М. (2006). Рагавыя сякеры Панямоння. Археалагічны зборнік 1, 5-10.

Charniauski, \& Kalinouski, 1972 = Чарняўскі, M.M. \& Каліноўскі, П.Ф. (1972). Рагавыя прылады працы са Смаргонскага месцазнаходжання. In Л.Д. Побаль (Ed.), Беларускія старажытнасиі: матэрыялы канферэнцыі па археалогіi БССР і сумежных тэрыторый, (рр. 26-32.) Мінск: Спинаи.

Chatters, J. C. (1987). Hunter-Gatherer adaptations and assemblage structure. Journal of Anthropological Archaeology, 6(4), 335-375. https://doi.org/10.1016/0278-4165(87)90005-5.

Clark, J. G. D. (1936). The Mesolithic Settlement of Northern Europe. Cambridge: University Press. 
Clarkson, C., Hiscock, P., MacKay, A., \& Shipton, C. (2018). Small, sharp, and standardized: global convergence in backed-microlith technology. In M. J. O’Brien, B. Buchanan, \& M. I. Eren (Eds.), Convergent Evolution in Stone-Tool Technology. Vienna Series in Theoretical Biology (pp. 175-200). Cambridge: The MIT Press.

Collard, M., \& Shennan, S. J. (2008). Patterns, process, and parsimony: studying cultural evolution with analytical techniques from evolutionary biology. In M. T. Stark, B. J. Bowser, \& L. Horne (Eds.), Cultural Transmission and Material Culture (pp. 17-33). Tucson: The University of Tucson Press.

Damlien, H. (2016). Eastern pioneers in westernmost territories? Current perspectives on Mesolithic huntergatherer large-scale interaction and migration within Northern Eurasia. Quaternary International, 419, 516. https://doi.org/10.1016/j.quaint.2014.02.023.

David, É. (2009). Show me how you make your hunting equipment and I will tell you where you come from: technical traditions, an efficient means of characterizing cultural identities. In S. McCartan, R. Schulting, G. Warren, \& P. Woodman (Eds.), Mesolithic Horizons. Papers presented at the Seventh International Conference on the Mesolithic in Europe, Belfast 2005 (pp. 243-247). Oxford: Oxbow books.

Edgren, T. (1997). Om fågelpilen. In A. Åkerlund, S. Bergh, J. Nordbladh, \& J. Taffinder (Eds.), Till Gunborg. Arkeologiska samtal (pp. 23-38.) Stockholm Archaeological Reports 33). Stockholm: Stockholm University.

Elston, R. G., \& Brantingham, P. J. (2002). Microlithic technology in northern Asia: a risk-minimizing strategy of the Late Paleolithic and Early Holocene. In R. G. Elston \& S. L. Kuhn (Eds.), Thinking Small: Global Perspectives on Microlithization (pp. 103-116). Archeological Papers of the American Anthropological Association 12(1). https://doi.org/10.1525/ap3a.2002.12.1.103.

Elston, R. G., Guanghui, D., \& Dongju, Z. (2011). Late Pleistocene intensification technologies in Northern China. Quaternary International, 242(2), 401-415. https://doi.org/10.1016/j.quaint.2011.02.045.

Elston, R. G., \& Kuhn, S. L. (Eds.). (2002). Thinking small: global perspectives on microlithization. Archeological Papers of the American Anthropological Association, 12(1), 103-116. https://doi.org/10. 1525/ap3a.2002.12.1.103.

Eriksson, G., Lõugas, L., \& Zagorska, I. (2003). StoneAge hunter-fisher-gatherers at Zvejnieki, northern Latvia: stable isotope and archaeozoological data. Before Farming, 2003/1, article 2. https://doi.org/10. 3828/bfarm.2003.1.2.

Fedje, D., Mackie, Q., McLaren, D., \& Christensen, T. (2008). A projectile point sequence for Haida Gwaii. In R. L. Carlson \& M. P. R. Magne (Eds.), Projectile Point Sequences in Northwestern North America (pp. 19-40). Burnaby, B.C.: Archaeology Press, Simon Fraser University.

Feurdean, A., Perșoiu, A., Tanțău, I., Stevens, T., Magyari, E. K., Onac, B. P., et al. (2014). Climate variability and associated vegetation response throughout Central and Eastern Europe (CEE) between 60 and 8 ka. Quaternary Science Reviews, 106, 206-224. https://doi.org/10.1016/j.quascirev.2014.06.003.

Fleitmann, D., Mudelsee, M., Burns, S. J., Bradley, R. S., Kramers, J., \& Matter, A. (2008). Evidence for a widespread climatic anomaly at around 9.2 ka before present. Paleoceanography, 23(1), 1-6. https://doi. org/10.1029/2007PA001519.

Friedel, E. (1872). Ueber Knochenpfeile aus Deutchland. Archiv für Anthropologie: Zeitschrift für Naturgeschichte und Urgeschichte des Menschen, 5, 433-436.

Glück, E. (1906). Über neolithische Funde in der Pärnu und die Urbewohner der Pernau-Gegend. Sitzungsberichte der Altertumforschenden Gesellschaft zu Pernau IV, 259-318.

Goebel, T., Waters, M. R., Buvit, I., Konstantinov, M. V., \& Konstantinov, A. V. (2000). Studenoe-2 and the origins of microblade technologies in the Transbaikal, Siberia. Antiquity, 74(285), 567-575. https://doi. org/10.1017/S0003598X00059925.

Gracheva, et al. 2006 = Грачева Р. Г., Сорокин А. Н., Малясова Е. С., Успенская О. Н., Чичагова О. А., \& Сулержицкий Л. Д. (2006). Культурные слои и погребенные почвы в условиях заболоченных зандровых равнин: возможности и ограничения методов археологических и природных реконструкций. In C.А Сычева, А.А. Узянов (Eds.), Культурные слои археологических памятников. Теория, методы и практика. Материалы научной конференции (рр. 186-211). Москва: Институт Археологии Российская Академия Наук.

Graf, K. E. (2010). Hunter-gatherer dispersals in the mammoth-steppe: technological provisioning and landuse in the Enisei River valley, south-central Siberia. Journal of Archaeological Science, 37(1), 210-223. https://doi.org/10.1016/j.jas.2009.09.034.

Grewingk, C. (1882). Geologie und Archaeologie des Mergellagers von Kunda in Estland. Archiv für Naturkunde Liv-, Est- und Kurlands. I Serie, Bd. IX, Lieferung 1. Dorpat.

Grewingk, C. (1887). Archäologische Ausflüge in Liv- und Estland. Sitzungsberichte der gelehrten estnischen Gesellschaft zu Dorpat, 1886, 153-177. 
Gummesson, S., \& Molin, F. (2019). Points of bone and antler from the Late Mesolithic settlement in Motala, eastern central Sweden. In D. Groß, D. Jantzen, H. Lübke, \& J. Meadows (Eds.), Working at the Sharp End: From Bone and Antler to Early Mesolithic Life in Northern Europe (pp. 1-25). Untersuchungen und Materialien zur Steinzeit in Schleswig-Holstein und im Ostseeraum 10. Kiel/Hamburg: Zentrum für Baltische und Skandinavische Archäologie.

Günther, T., Malmström, H., Svensson, E. M., Omrak, A., Sánchez-Quinto, F., Kılınç, G. M., Krzewińska, M., Eriksson, G., Fraser, M., Edlund, H., Munters, A. R., Coutinho, A., Simões, L. G., Vicente, M., Sjölander, A., Jansen Sellevold, B., Jørgensen, R., Claes, P., Shriver, M. D., Valdiosera, C., Netea, M. G., Apel, J., Lidén, K., Skar, B., Storå, J., Götherström, A., \& Jakobsson, M. (2018). Population genomics of Mesolithic Scandinavia: Investigating early postglacial migration routes and high-latitude adaptation. PLOS Biology, 16(1), e2003703. https://doi.org/10.1371/journal.pbio.2003703.

Gurina 1956 = Гурина, Н.Н. (1956). Оленеостровский могильник. Материалы и исследования по археологии СССР 47. Москва-Ленинград: Наука.

Hartz, S. T., Terberger, T., \& Zhilin, M. (2010). New AMS-dates for the Upper Volga Mesolithic and the origin of microblade technology in Europe. Quartär, 57, 155-169. https://doi.org/10.7485/QU57 08.

Helwig, K., Monahan, V., \& Poulin, J. A. (2008). The identification of hafting adhesive on a slotted antler point from a Southwest Yukon ice patch. American Antiquity, 73(2), 279-288. https://doi.org/10.1017/ S000273160004227X.

Hertell, E., \& Tallavaara, M. (2011). Hunter-gatherer mobility and the organization of core technology in Mesolithic North-Eastern Europe. In T. Rankama (Ed.), Mesolithic Interfaces: Variability in Lithic Technologies in Eastern Fennoscandia (pp. 95-110). Monographs of the Archaeological Society of Finland 1). Helsinki: Archaeological Society of Finland.

Indreko, R. (1926). Die Rambachsche Sammlung. Sitzungsberichte der Altertumforschenden Gesellschaft zu Pernau VIII, 1914-1925, 283-344.

Indreko, R. (1936). Vorläufige Bemerkungen über die Kunda Funde. Sitzungsberichte der Gelehrten Estnischen Gesellschaft, 1934, 225-298.

Indreko, R. (1948). Die Mittlere Steinzeit in Estland. Kungl. Vitterhets Historie och Antikvitets Akademiens Handlingar 66. Stockholm: Wahlström \& Widstrand.

Ivanovaitė, L., Bjørnevad, M., Philippsen, B., Hoggard, C., Enghild, J. J., Scavenius, C., et al. (2018). Making silent bones speak: The analysis of orphaned osseous tools illustrated with Mesolithic stray finds. Archaeologia Baltica, 25, 53-70. https://doi.org/10.15181/ab.v25i0.1830.

Jaanits, L. (1965). Über die Ergebnisse der Steinzeitforschung in Sowjetestland. Finskt Museum LXXII, 5-46. Jonuks, T. (2013). An antler object from the Pärnu River - an axe, a god or a decoy? In K. Johanson \& M. Tõrv (Eds.), Man, his time, artefacts, and places: collection of articles dedicated to Richard Indreko (pp. 225-246). Muinasaja teadus 19). Tartu: University of Tartu.

Jonuks, T. (2016). A Mesolithic human figurine from River Pärnu, South-West Estonia: a century old puzzle of idols, goddesses and ancestral symbols. Estonian Journal of Archaeology, 20(1), 111-127. https://doi. org/10.3176/arch.2016.2.01.

Jungklaus, B., Kotula, A., \& Terberger, T. (2016). New investigations into the Mesolithic burial of Groß Fredenwalde, Brandenburg - first results. In J. M. Grünberg, B. Gramsch, L. Larsson, J. Orschiedt, \& H. Meller (Eds.), Mesolithic burials - Rites, symbols and social organisation of early postglacial communities (pp. 419-432). Tagungen des Landesmuseums für Vorgeschichte Halle 13/I). Halle: Landesmuseums für Vorgeschichte Halle.

Jussila, T., Kriiska, A. \& Rostedt, T. (2012). Saarenoja 2 - an Early Mesolithic site in South-Eastern Finland. Preliminary results and interpretations of studies Conducted in 2000 and 2008-10. Fennoscandia archaeologica XXIX, 3-27.

Kalinouski 1983 = Калиновский, П.Ф. (1983). Териофауна позднего антропогена и голоцена Белоруссии. Минск: Наука и техника.

Kalinouski 1995 = Каліноўскі, П.Ф. (1995). Драпежныя звяры са Смаргонскага месцазнаходжання. Лimacфepa 2, 47-57.

Kashuba, N., Kirdök, E., Damlien, H., Manninen, M. A., Nordqvist, B., Persson, P., \& Götherström, A. (2019). Ancient DNA from chewing gums solidifies connection between material culture and genetics of Mesolithic hunter-gatherers in Scandinavia. Communications Biology, 2(1), 185. https://doi.org/10.1038/ s42003-019-0399-1.

Kjällquist, M. (2001). Gåvor eller avfall? En studie av sex mesolitiska gravar från Tågerup. In P. Karsten \& B. Knarrströn (Eds.), Tågerup specialstudier. Skånska spår - arkeologi längs Västkustbanan (pp. 32-69). Lund: Riksantikvarieämbetet.

Kjällquist, M., Emilsson, A., \& Boethius, A. (2016). Norje Sunnansund. Boplatslämningar från tidigmesolitikum och järnålder. Särskild arkeologisk undersökning 2011 och arkeologisk 
förundersökning 2011 och 2012, Ysane socken, Sölvesborgs kommun i Blekinge län. Karlskrona: Blekinge museum.

Knutsson, H., Knutsson, K., Molin, F., \& Zetterlund, P. (2016). From flint to quartz: organization of lithic technology in relation to raw material availability during the pioneer process of Scandinavia. Quaternary International, 424, 32-57. https://doi.org/10.1016/j.quaint.2015.10.062.

Kriiska, A., Rostedt, T., \& Jussila, T. (2016). The development of early Mesolithic social networks during the settlement of virgin lands in the eastern Baltic Sea region interpreted through comparison of two sites in Finland. In L. Melheim, H. Glørstad, \& Z. Glørstad (Eds.), Comparative Perspectives on Past Colonisation, Maritime Interaction and Cultural Integration (pp. 19-40). New Directions in Anthropological Archaeology). South Yorkshire: Equinox publishing.

Kryvaltsevich 1996 = Крывальцэвіч, М. (1996). Касцяныя і рагавыя вырабы каменнага веку з возера Вячэра. In А.К. Краўцэвіч (Ed.), 3 гльгбі вякоў. Наш край: гістарычна-культуралагічны зборнік 1 (pp. 147-168). Minsk: Навука і тэхніка.

Kryvaltsevich 1999 = Крывальцэвіч, М.M. (1999). Азярное 1 - паселішча эпохі бронзы на поўначы Палесся. Мінск: Інстытут гісторыі Нацыянальнай акадэміі навук Беларусі.

Kryvaltsevich 2008 = Крывальцэвіч, М. (2008). Гравіраваныя выявы і арнаментальнае аздабленне на касцяных вырабах з возера Вячэра. In J. Bednarczyk, J. Czebreszuk, P. Makarowicz \& M. Szmyt (Eds.), Na pograniczu światów : studia z pradziejów międzymorza baltycko-pontyjskiego ofiarowane Profesorowi Aleksandrowi Kośko w 60. rocznice urodzin (, pp. 245-256). Poznań: Wydawnictwo Poznańskie.

Kryvaltsevich \& Simakova 2004 = Кривальцевич, Н. \& Симакова, Г. (2004). Микрорегион озера Вечера (Предполесье Беларуси): основные этапы освоения и использования (по археологическим и пыльцевым данным). Гістарычна-археалагічны зборнік 19, 11-27.

Kudrashou 1997 = Кудрашоў, В.Я. (1997). Помнікі кудлаеўскай культуры. In: М.М. Чарняўскі \& А.Г. Калечыц (Eds.), Археалогія Беларусі, T. 1: Каменны і бронзавы вякі (рр. 76-81). Мінск: Беларуская навука.

Kudrashou \& Kryvaltsevich 1994 = Кудряшов, В.Е. \& Кривальцевич, Н.Н. (1994). Озерное-1 - новый памятник кудлаевской культуры эпохи мезолита в Белорусском Полесье. Гістарычнаархеаласічны зборнік 5, 87-102.

Langlais, M., Laroulandie, V., Costamagno, S., Pétillon, J.-M., \& Mallye, J.-b., Lacrampe-Cuyaubere, F., et al. (2015). Premiers temps du Magdalénien en Gironde: réévaluation des fouilles Trécolle à Saint-Germainla-Rivière (France). Bulletin de la Société préhistorique française, 112(1), 5-58. https://doi.org/10.3406/ bspf.2015.14489.

Larsson, L. (1990). The Mesolithic of Southern Scandinavia. Journal of World Prehistory, 4(3), $257-309$. https://doi.org/10.1007/BF00974882.

Larsson, L. (2005). Regional or interregional representation? A slotted bone dagger from Offerdal, Jämtland. In R. Engelmark, T. B. Larsson \& L. Rathje (Eds.), En lång historia... Festskrift till Evert Baudou på 80årsdagen (pp. 261-273). Archaeology and Environment 19 \& Kungliga Skytteanska Samfundets Handlingar 57. Umeå: Umeå University.

Lewis, L., Perera, N., \& Petraglia, M. (2014). First technological comparison of Southern African Howiesons Poort and South Asian Microlithic industries: An exploration of inter-regional variability in microlithic assemblages. Quaternary International, 350, 7-25. https://doi.org/10.1016/j.quaint.2014.09.013.

Lidén, O. (1942). De flinteggade benspetsarnas nordiska kulturfas. Studier i anslutning till nya sydsvenska fynd. Skrifter utgivna av Kung. Humanistiska Vetenskapssamfundet $i$ Lund, XXXIII. Lund: Kung. Humanistiska Vetenskapssamfundet.

Lozovskaya, O., \& Lozovski, V. (2013). Barbed points from the site of Zamostje 2. In V. M. Lozovski, O. V. Lozovskaya, \& I. Clemente Conte (Eds.), Zamostje 2. Lake settlement of the Mesolithic and Neolithic fisherman in Upper Volga region (pp. 77-109). Russian Academy of Science Institute for the History of Material Culture: St. Petersburg.

Mace, R., \& Pagel, M. D. (1994). The comparative method in anthropology. Current Anthropology, 35(5), 549-564.

Madsen, D. B., Li, J., Brantingham, P. J., Gao, X., Elston, R. G., \& Bettinger, R. L. (2001). Dating Shuidonggou and the Upper Paleolithic blade industry in North China. Antiquity, 77, 706-716.

Malyutina, et al. 2019 = Малютина, А.А., Вашанов, А.Н., Ткачева, М.И. \& Ткач, Е.С. (2019). Техникоморфологические особенности одной категории роговых орудий из местонахождения у д. Михневичи (северо-западная Беларусь). Самарский научный вестник 8/4 (29), 116-122.

Manem, S. (2020). Modeling the evolution of ceramic traditions through a phylogenetic analysis of the Chaînes Opératoires: the European Bronze Age as a case study. Journal of Archaeological Method and Theory., 27(4), 992-1039. https://doi.org/10.1007/s10816-019-09434-w. 
Manninen, M. A., Damlien, H., Kleppe, J. I., Knutsson, K., Murashkin, A., Niemi, A. R., Rosenvinge, C. S., \& Persson, P. (2021). First encounters in the north. Cultural diversity and gene flow in Early Mesolithic Scandinavia. Antiquity, First view, 1-19. https://doi.org/10.15184/aqy.2020.252.

Manninen, M. A., Hertell, E., Pesonen, P., \& Tallavaara, M. (2018). Postglacial pioneer colonisation of eastern Fennoscandia: modeling technological change. In H. Glørstad, J. Apel, H. Knutsson, \& K. Knutsson (Eds.), The Early Settlemet of Northern Europe. Transmission of Knowledge and Culture, vol. 2 (pp. $23-$ 46). Sheffield: Equinox Publishing.

Manninen, M. A., \& Knutsson, K. (2014). Lithic raw material diversification as an adaptive strategy technology, mobility, and site structure in Late Mesolithic northernmost Europe. Journal of Anthropological Archaeology, 33, 84-98. https://doi.org/10.1016/j.jaa.2013.12.001.

Miettinen, A., Sarmaja-Korjonen, K., Sonninen, E., Jungner, H., Lempiäinen, T., Ylikoski, K., et al. (2008). The palaeoenvironment of the 'Antrea net find'. Iskos, 16, 71-87.

Molin, F., \& Wikell, R. (2009). Microblade Technology in Quartz during the Mesolithic in Eastern Middle Sweden. Current Swedish Archaeology, 15-16(2007/2008), 137-156.

Nikolaev, et al. 2002 = Николаев В.И., Якумин П., Александровский А.Л., Белинский А.Б., Демкин В.А., Женони Л., et al. (2002). Среда обитания человека в голоцене по данным изотопногеохимических и почвенно-археологических исследований (Европейская часть России). Москва: Институт Археологии Российская Академия Наук.

Nirgi, T., Rosentau, A., Hando-Laur, H., Hang, T., Jonuks, T., Jõeleht, A., et al. (2019). Holocene relative shore-level changes and Stone Age palaeogeography of the Pärnu Bay area, eastern Baltic Sea. The Holocene, 30(1), 37-52. https://doi.org/10.1177/0959683619865603.

O’Brien, M. J., Lyman, R. L., Collard, M., Holden, C. J., Gray, R. D., \& Shennan, S. J. (2008). Transmission, Phylogenetics, and the Evolution of Cultural Diversity. In M. J. O'Brien (Ed.), Cultural Transmission and Archaeology: Issues and Case Studies (pp. 39-58). Washington: Society for American Archaeology Press.

Okladniukov 1950 = Окладников А.П. (1950). Неолит и бронзовый век Прибайкалья I-II. Материалы и исследования по археологии СССР 18. Москва. Ленинград: Издательство Академии Наук СССР.

Olofsson, A. (2002). Microblade technology in Northern Sweden: chronological and cultural implications. Current Swedish Archaeology, 10, 73-94.

Oshibkina, S. V. (1989). The material culture of the Veretye-type sites in the region to the east of the Lake Onega. In C. Bonsall (Ed.), The Mesolithic in Europe: Papers Presented at the Third International Symposium, Edinburgh 1985 (pp. 402-413). Edinburgh: John Donald Publishers.

Osipowicz, G., Orłowska, J., Bosiak, M., Manninen, M. A., Targowski, P., \& Sobieraj, J. (2020). Slotted bone point from Tłokowo - rewritten story of unique artefact from Mesolithic Poland. Accepted for publication in Praehistorische Zeitschrift, 95(2), 334-349.

Pälsi, S. (1920). Ein Steinzeitlicher Moorfund bei Korpilahti im Kirchspiel Antrea Län Viborg. SMYA-FFT, 28(2), 1-19.

Persson, P. (2014). Prestemoen 1. En plats med ben från mellanmesolitikum. In S. A. Melvold \& P. Persson (Eds.), Vestfoldbaneprosjektet. Arkeologiske undersøkelser i forbindelse med ny jernbane mellom Larvik og Porsgrunn. Bind 1. Tidlig- og mellommesolittiske lokaliteter $i$ Vestfold og Telemark (pp. 202-227). Portal: Kristiansand.

Pétillon, J.-M., Bignon, O., Bodu, P., Cattelain, P., Debout, G., Langlais, M., Laroulandie, V., Plisson, H., \& Valentin, B. (2011). Hard core and cutting edge: experimental manufacture and use of Magdalenian composite projectile tips. Journal of Archaeological Science, 38(6), 1266-1283. https://doi.org/10.1016/j. jas.2011.01.002.

Philippsen, B. (2019). Approaches to determine reservoir effects in elk/moose. Radiocarbon, 61(6), 18891904. https://doi.org/10.1017/RDC.2019.124.

Philippsen, B., Ivanovaite, L., Makhotka, K., Sauer, F., Riede, F., \& Olsen, J. (2019). Eight New Late Pleistocene/Early Holocene AMS Dates from the Southeastern Baltic. Radiocarbon, 61(2), 615-627. https://doi.org/10.1017/RDC.2018.153.

Praslov \& Rogachev 1982 = Праслов, Н.Д. \& Рогачев, А.Н. (Eds.), (1982). Палеолит КостенковскоБориевского района на Дону. 1879-1979. Некоторые итоги полевых исследований. Lenindgrad: Наука.

Qu, T., Bar-Yosef, O., Wang, Y., \& Wu, X. (2012). The Chinese Upper Paleolithic: geography, chronology, and techno-typology. Journal of Archaeological Research, 21(1), 1-73. https://doi.org/10.1007/s10814012-9059-4.

Rabett, R. J., \& Piper, P. J. (2011). The emergence of bone technologies at the end of the Pleistocene in Southeast Asia: regional and evolutionary implications. Cambridge Archaeological Journal, 22(1), 3756. https://doi.org/10.1017/S0959774312000030. 
Rasmussen, S. O., Andersen, K. K., Svensson, A. M., Steffensen, J. P., Vinther, B. M., Clausen, H. B., et al. (2006). A new Greenland ice core chronology for the last glacial termination. Journal of Geophysical Research-Atmospheres, 111, D06102.

Reimer, P. J., Austin, W. E. N., Bard, E., Bayliss, A., Beck, J. W., Blackwell, P. G., et al. (2020). The IntCal20 northern hemisphere radiocarbon age calibration curve (0-55 cal kBP). Radiocarbon, 62(4), 725-757. https://doi.org/10.1017/RDC.2020.41.

Reynolds, N., \& Riede, F. (2019). House of cards: cultural taxonomy and the study of the European Upper Palaeolithic. Antiquity, 93, 1350-1358. https://doi.org/10.15184/aqy.2019.49.

Rosentau, A., Veski, S., Kriiska, A., Aunap, R., Vassiljev, J., Saarse, L., Hang, T., Heinsalu, A., \& Oja, T. (2011). Palaeogeographic model for the SW Estonian coastal zone of the Baltic Sea. In J. Harff, S. Björck, P. Hoth, \& P. (Eds.), The Baltic Sea Basin (pp. 165-188). Berlin: Heidelberg.

Rostedt, T., \& Kriiska, A. (2019). Quartz assemblage from the early Mesolithic Helvetinhaudanpuro settlement site in Eastern Central Finland. Vestnik of Saint Petersburg University, History, 64(2), 639-665. https://doi.org/10.21638/11701/spbu02.2019.213.

Sander, K., \& Kriiska, A. (2015). Archaeological test excavations at the Stone Age site Kunda Lammasmägi in 2013-2014. Archaeological Fieldwork in Estonia, 2014, 29-38.

Sander, K., \& Kriiska, A. (2018). New archaeological data and paleolandscape reconstructions of the basin of an Early and Middle Holocene lake near Kunda. North-Eastern Estonia. Fennoscandia archaeologica $X X X V, 65-85$.

Sarauw, G. (1904). En stenalders boplads i Maglemose ved Mullerup sammenholdt med beslcegtede fund: Études sur le premier age de la pierre du Nord de l'Europe. København: H.H. Thieles Bogtrykkeri.

Savchenko \& Zhilin 2018 = Савченко, С.Н. \& Жилин М.Г. (2018). Шигирские находки в собрании музея антропологии и этнографии им. Петра Великого (Кунсткамера). Camera praehistorica 1, 94-105.

Schild, R., Tobolski, K., Kubiak-Martens, L., Bratlund, B., Eicher, U., Calderoni, G., et al. (2003). Hatvesting pike at Tłokowo. In L. Larsson, H. Kindgren, K. Knutsson, D. Loeffler, \& A. Åkerlund (Eds.), Mesolithic on the Move. Papers presented at the Sixth International Conference on the Mesolithic in Europe Stockholm 2000 (pp. 149-155). Oxford: Oxbow Books.

Schulz, H.-P. (1996). Pioneerit pohjoisessa. Suomen varhaismesoliittinen asutus arkeologisen aineiston valossa. Suomen Museo, 1996, 5-45.

Seppä, H., Birks, H. H., \& Birks, H. J. B. (2002). Rapid climatic changes during the Greenland stadial 1 (Younger Dryas) to early Holocene transition on the Norwegian Barents Sea coast. Boreas, 31(3), 215225. https://doi.org/10.1111/j.1502-3885.2002.tb01068.x.

Seppä, H., Bjune, A. E., Telford, R. J., Birks, H. J. B., \& Veski, S. (2009). Last nine-thousand years of temperature variability in Northern Europe. Climate of the past, 5, 523e535.

Sidorov \& Sorokin 1997 = Сидоров В. В. \& Сорокин А. Н. (1997). Многослойное поселение Замостье 5. Древности Залесского края. Материальк кмежуународной конференции Каменный век Европейских равнин (рp. 144-163). Сергиев-Посад: Сергиево-Посадский музей-заповедник.

Sidorov \& Sorokin 1998 = Сидоров В.В. \& Сорокин А.Н. (1998). Раскопки многослойного поселения Замостье 5. Тверской археологический сборник 3, 226-237.

Sidorov \& Sorokin 2001= Сидоров В.В. \& Сорокин А.Н. (2001). Многослойная стоянка Замостье 5. Материаль международной конференции. Каменный век Европейских равнин: объекты из органических материалов и структура поселений как отражение человеческой культуры. Сергиев-Посад. 1-5 июля 1997 (рр. 142-146). Сергиев-Посад: Сергиево-Посадский музейзаповедник.

Sidorov, V., \& Sorokin, A. (2000). The discovery and investigation of a multi-layer settlement at Zamostje 5 on the Russian Plain. In T. Darvill, G. H. Afanas'ev, \& E. Wilkes (Eds.), Anglo-Russian Archaeology Seminar: Recording Systems for Archaeological Projects (pp. 1-25). Bournemouth University School of Conservation Sciences Research Report 6). Bournemouth and Moscow: Bournemouth University and the Russian Academy of Sciences.

Sjöström, A., \& Hammarstrand Dehman, K. (2010). Mesolitiska lämningar i Rönneholms mosse. Arkeologisk förundersökning 2009. Hassle 32:18, Stehag socken, Eslövs kommun, Skåne. Lund: Institutionen för arkeologi och antikens historia, Lunds universitet.

Skakun, N. N., Zhilin, M. G., \& Terekhina, V. V. (2011). Technology of the processing of bone and antler at Ivanovskoje 7 Mesolithic site, Central Russia. Rivista di Scienze preistoriche, 61, 39-58.

Söderlind, S. (2018). A Study of the Mesolithic Handle Core Technology in Schleswig-Holstein. Archäologische Informationen, 41, 305-316. https://doi.org/10.11588/ai.2018.0.56949.

Sørensen, M., Rankama, T., Kankaanpää, J., Knutsson, K., Knutsson, H., Melvold, S., Eriksen, B. V., \& Glørstad, H. (2013). The first eastern migrations of people and knowledge into Scandinavia: evidence 
from studies of Mesolithic technology, 9-8 millennium BC. Norwegian Archaeological Review, 46(1), 19-56. https://doi.org/10.1080/00293652.2013.770416.

Sørensen, S. A. (2017). The Kongemose Culture. Copenhagen: University Press of Southern Denmark.

Sorokin 2000 = Сорокин, А.Н. (2000). Заболотский торфяник: что сделано, что делать? Тверской археологический сборник 4(1), 131-136.

Sorokin 2007 = Сорокин А.Н. (2007). Памятники Заболотского торфяника. Институт археологии. Российской академии наук. Москва: Институт Археологии Российская Академия Наук.

Sorokin 2009 = Сорокин А.Н. (2009). Заболотский торфяник: находки и проблемы. Макаров, Н.А. (Ред.) Археологические открытия 1991-2004 Европейская Россия (рp. 82-94). Москва: Институт Археологии Российская Академия Наук.

Sorokin $2010=$ Сорокин А.Н. (2010). Пионеры Европейской России (по материалам исследований могильника Минино 2 в 2006-2007 гг.). In А.П. Деревянко, А.Б. Куделин \& B.А. Тишков (Eds.), Адаптация народов и культур к изменениям природной среды, социальным и техногенным трансформациям (рp. 66-73). Москва: Российская политическая энциклопедия (РОССПЭН). http://adaptation.iea.ras.ru/reports/final/ADAP_1.pdf

Sorokin 2011 = Сорокин, А.Н. (2011). Стоянка и могильник Минино 2 в Подмосковье. Moscow: Russian Academy of Sciences.

Sorokin 2013 = Сорокин, А.Н. (2013). Стоянка и могильник Минино 2 в Подмосковье: костяной и роговой инвентарь. Москва: Институт Археологии Российская Академия Наук. http://www. archaeolog.ru/media/books_2013/Sorokin.pdf

Sorokin 2016 = Сорокин А.Н. (2016). Некоторые результаты изучения геоархеологических объектов Заболотского торфяника (Московская область, Россия). Пути эволюиионной географии: Материаль Всероссийской научной конференщии, посвящённой памяти профессора А. А. Величко (Москва, 23-25 ноября 2016 г.) (рp. 716-721). Москва: Институт Археологии Российская Академия Наук.

Sorokin \& Hamakawa 2014 = Сорокин А.Н. \& Хамакава М. (2014). Геоархеологические объекты Заболотского торфяника на территории Европейской России. Известия Иркутского госуниверситета. Геоархеология. Этнология. Антропология 10, 50-93.

Sorokin et al. 2018 = Сорокин А.Н., Грачёва Р.Г., Добровольская Е.В. \& Добровольская, М.В. (2018). Геоархеология Заболотского края (13 500-7 500 cal BC). Москва: Институт Археологии Российская Академия Наук.

Sorokin, et al. 2019 = Сорокин А. Н., Панин А. В., Грачёва Р. Г., Солодков Н. Н., Ставицкий В. В., Смирнов А. Л., et al. (2019). Заболотский отряд. Resource document. www.archaeolog.ru/ru/ expeditions/expeditions-2019/zabolotskiy-otryad\%2D\%2D2019.

Stahl, A. B., \& Roddick, A. P. (2016). Knowledge in Motion: Constellations of Learning Across Time and Place, Amerind series in anthropology. Tucson, AZ: The University of Arizona Press.

Sten, S., Ahlström, T., Alexandersen, V., Borrman, H., Christensen, E., Ekenman, I., et al. (2000). Barumkvinnan. Nya forskningsrön. Fornvännen, 95, 73-87.

Sulgostowska, Z., \& Hoffman, M. (1993). Kościane ostrze mezolityczne z wkładkami krzemiennymi z Tłokowa, woj. Olsztyńskie - Aspekt technologiczny. Archeologia Polski, XXXVIII/1, 75-87.

Tallavaara, M., Manninen, M. A., Hertell, E., \& Rankama, T. (2010). How flakes shatter: a critical evaluation of quartz fracture analysis. Journal of Archaeological Science, 37(10), 2442-2448. https://doi.org/10. 1016/j.jas.2010.05.005.

Tomasso, A., Rots, V., Purdue, L., Beyries, S., Buckley, M., Cheval, C., Cnuts, D., Coppe, J., Julien, M. A., Grenet, M., Lepers, C., M'hamdi, M., Simon, P., Sorin, S., \& Porraz, G. (2018). Gravettian weaponry: 23, 500-year-old evidence of a composite barbed point from Les Prés de Laure (France). Journal of Archaeological Science, 100, 158-175. https://doi.org/10.1016/j.jas.2018.05.003.

Tõrv, M. (2018). Persistent Practices A Multi-Disciplinary Study of Hunter-Gatherer: Mortuary Remains from c. 6500-2600 cal. BC, Estonia. Untersuchungen und Materialien zur Steinzeit in Schleswig-Holstein aus dem Archäologischen Landesmuseum der Stiftung Schleswig-Holsteinische Landesmuseen Schloss Gottorf 9. Hamburg: Wachholtz Verlag.

Trusov 2011 = Трусов А.В. (2011). Палеолит бассейна Оки. Моscow: Репроцентр-М.

Tsvetkova, N. A. (2017). Slotted Weaponry of the Mesolithic — Early Neolithic in the Upper Volga Region. Stratum plus, 1, 127-154.

Uvarov 1881 = Уваров А.С. (1881). Археология России. Каменный период. Синодальная типография.

Vahur, S., Kriiska, A., \& Leito, I. (2011). Investigation of the adhesive residue on the flint insert and the adhesive lump found from the Pulli Early Mesolithic settlement site (Estonia) by micro-ATR-FT-IR spectroscopy. Estonian Journal of Archaeology, 15(1), 3-17. https://doi.org/10.3176/arch.2011.1.01. 
Vang Petersen, P. (2001). Tuse Hauge. Arkaeologiske udgravninger i Danmark 2001 (p. 277). Copenhagen: Rigsantikvarens Arkæologiske Sekretariat.

Veski, S., Seppä, H., Stančikaitė, M., Zernitskaya, V., Reitalu, T., Gryguc, G., Heinsalu, A., Stivrins, N., Amon, L., Vassiljev, J., \& Heiri, O. (2015). Quantitative summer and winter temperature reconstructions from pollen and chironomid data between 15 and 8 ka BP in the Baltic-Belarus area. Quaternary International, 388, 4-11. https://doi.org/10.1016/j.quaint.2014.10.059.

Wadley, L. (2015). Those marvellous millennia: the Middle Stone Age of Southern Africa. Azania: Archaeological Research in Africa, 50(2), 155-226. https://doi.org/10.1080/0067270X.2015.1039236.

Yi, M., Barton, L., Morgan, C., Liu, D., Chen, F., Zhang, Y., Pei, S., Guan, Y., Wang, H., Gao, X., \& Bettinger, R. L. (2013). Microblade technology and the rise of serial specialists in north-central China. Journal Anthropological Archaeology, 32(2), 212-223. https://doi.org/10.1016/j.jaa.2013.02.001.

Zaretskaya, N. E., Zhilin, M. G., Karmanov, V. N., \& Uspenskaya, O. N. (2005). Radiocarbon dating of Wetland Mesolithic-Neolithic Archaeological Sites within the Upper Volga and Middle Vychegda. Geochronometria. Journal on Methods and Applications of Absolute Chronology, 24, 117-131.

Zhilin 2019 = Жилин М.Г. (2019). Вкладышевые кинжалы и охотничьи ножи в мезолите Восточной Европы. Краткие сообщения Института археологии 255, 50-70.

Publisher's Note Springer Nature remains neutral with regard to jurisdictional claims in published maps and institutional affiliations.

\section{Affiliations}

\section{Mikael A. Manninen ${ }^{1}$ • Vitali Asheichyk ${ }^{2}$ - Tõnno Jonuks ${ }^{3}$ - Aivar Kriiska ${ }^{4}$ • Grzegorz Osipowicz $^{5}$ • Aleksei Nikolaevich Sorokin ${ }^{6} \cdot$ Aliaksandr Vashanau $^{7}$ • Felix Riede ${ }^{8}$. Per Persson ${ }^{9}$}

1 Ecosystems and Environment Research Programme and Helsinki Institute of Sustainability Science (HELSUS), Faculty of Biological and Environmental Sciences, University of Helsinki, Viikinkaari 1, P.O. Box 65, Helsinki, Finland

2 Minsk, Belarus

3 Estonian Literary Museum, Vanemuise 42, 51003 Tartu, Estonia

4 Institute of History and Archaeology, University of Tartu, Jakobi 2, 51005 Tartu, Estonia

5 Institute of Archaeology, Nicolaus Copernicus University, Szosa Bydgoska 44/48st, 87-100 Toruń, Poland

6 Department of Cultural Heritage, Institute of Archaeology of RAS, 19, Dm. Ulianova st, Moscow, Russia 117292

7 Institute of History, National Academy of Sciences of Belarus, Akademičnaja st. 1, 220072 Minsk, Belarus

8 Department of Archaeology and Heritage Studies, Aarhus University, Moesgård Allé 20, 8270, Højbjerg, Denmark

9 Museum of Cultural History, University of Oslo, PO box 6762, St. Olavs plass, NO-0130, Oslo, Norway 